\title{
PIĘTNASTOWIECZNY KODEKS RECKOPIŚMIENNY Z LISTAMI I MOWAMI ENEASZA SYLWIUSZA PICCOLOMINIEGO W ZBIORACH BIBLIOTEKI UNIWERSYTECKIEJ KUL
}

W zbiorach rękopiśmiennych Biblioteki Uniwersyteckiej KUL pod sygnatura nr 2625 znajduje się piętnastowieczny rękopis z kopiami listów i mów Eneasza Sylwiusza Piccolominiego. Kodeks ma wymiary $23 \times 15 \mathrm{~cm}$. Rękopis oprawiony jest w deski obciągnięte skórą, oprawa współczesna. Wierzchnia część oprawy zachowana jest w całości, skóra mocno przytwierdzona do deski, deska nieuszkodzona, z tylniej części oprawy został tylko fragment deski i nieprzytwierdzona, nieco poszarpana skóra. Na skórze części wierzchniej dziury po okuciach metalowych i tłoczony ornament $\mathrm{z}$ motywem owocu granatu oraz kwiaty w okręgach, natomiast na skórze tylnej części oprawy - kratka. Karty kodeksu sa papierowe, paginowane i łącznie liczą 588 stron. W dwóch miejscach znajdują się pomyłki w numeracji - po stronie 38 następują dwie nieliczbowane strony, po nich zaś dopiero strona 39; podobnie po stronie 500 sa także dwie nienumerowane strony i dopiero po nich następuje strona 501 .

Do roku 2003 kodeks pozostawał w nieopracowanych zbiorach rękopiśmiennych Biblioteki KUL. W trakcie bibliotecznego opracowania we wrześniu 2003 roku ustaliłam, iż jest to kodeks pochodzący z biblioteki hrabiego Jerzego Szembeka z Poręby i znany był profesorowi Józefowi Szujskiemu, który korzystał z niego przy wydawaniu pierwszego tomu Codex epistolaris saeculi decimi quinti ${ }^{1}$. Na temat rękopisu Józef Szujski przekazał tylko krótką informację we wstępie do Codex epistolaris: „Kodeks in quarto biblioteki hr. Jerzego Szembeka w drewnianej oprawie skórą pokrytej, na wewnątrz której jest dyplomat tyczący się parafialnego kościoła w Brzesye Gnesnensis dioecesis, z datą obciçtą, pismem

${ }^{1}$ Codex epistolaris saeculi decimi quinti, ed. A. Sokołowski et J. Szujski, t. 1, w: Monumenta medii aevi historica, t. 2, Kraków 1876. 
z końca XV wieku. Kart 587². Barbarzyńska ręka powydzierała w wielu miejscach karty, miejscami udzierała je w połowic. Rozpoczyna się od polemicznego listu Zbigniewa do Eneasza z roku 1453, który tutaj w całości, chociaż w niezmiernie nieczytelnym znajduje się odpisie. Od stronicy 23-49, od 99-187, od 215-279 i od 379-395 znajdują się listy Eneasza i korespondencja polityczna cesarza Fryderyka z lat 1444-1454 pismem drobnem, włoskim, które następnie pisarz brzydką kursywą gotycką piszący wcześniejszymi i współczesnymi odpisami mów, listów, innych także osób, mianowicie Jana Castiglione, biskupa Pawii, uzupełniał. Znak wodny wskazuje początek obcy kodeksu, który w Polsce mógł być oprawionym" ". Tak jak stwierdził profesor Szujski, rękopis jest zdefektowany. Śladów po wyrwanych kartkach jest w rękopisie wiele, w większości miejsc numeracja pozostaje jednak nieprzerwana, co dowodzi, że te defekty powstały zanim została ona sporządzona, są to zatem zniszczenia dawne. Niestety ręka dewastatora dotknęła rękopis ponownie, gdyż są również miejsca, gdzie numeracja jest przerwana i sa ślady po wyrwanych kartach, których jest odpowiednio tyle, ile obejmowałyby zaginione strony. Od czasów Szujskiego brakuje jednej karty w liście Zbigniewa Oleśnickiego do Eneasza Sylwiusza (s. 5 i 6), został on jednak w cakości opublikowany przez Szujskiego, więc zaginiony tekst nie uległ bezpowrotnemu zatraceniu. Brak jest również czterech kart obejmujących strony 89-96, które były prawdopodobnie niezapisane oraz karty ze stronami 343 i 344, a te nie sájuż możliwe do odtworzenia. Mimo tych defektów rękopis nadal jest w dobrym stanie, pismo jest czytelne, karty sa czyste i suche, tylko brzegi poczerniały od wilgoci, na szczęście pleśń nie zaatakowała rękopisu w miejscach, gdzie znajduje się tekst. Wiele listów i mów zachowało się w całości, spośród zdefektowanych przeważnie ocalały duże partie tekstów, kilka tylko zaginçło zupełnie lub pozostalo w zbyt małym fragmencie, by można bylo stwierdzić, co zawierają. Pewnemu zniszczeniu uległa też oprawa, która, sądząc z opisu Szujskiego, była wtedy jeszcze zachowana w całości. Niestety po wspomnianym dokumencie na wewnętrznej stronie oprawy nie ma już śladu, deskę natomiast wyklejono kartką $\mathrm{z}$ adnotacją $w$ języku niemieckim. Paginacja pochodzi z połowy dziewiętnastego wieku i z dużym prawdopodobieństwem można przyjąć, iż została sporządzona ręką samego profesora Józefa Szujskiego. Przypuszczenie to bierze się stąd, iż paginowała kodeks ta sama ręka, która na pierwszej stronie w prawym górnym rogu uczyniła notatkę „Drukowane w dodatkach do Oleśnickiego II, niedokładnie”. Tę samą informację podaje Józef Szujski w swoim Codex epistolaris pod listem Zbigniewa Oleśnickiego do Eneasza Sylwiusza drukowanym na podstawie kodeksu hr. Jerzego Szembeka ${ }^{4}$, ponadto z łatwością można zauważyć, że delikatne podkreślenia słów na rękopisie uczyniono tym samym czarnym piórem, którym

${ }^{2}$ Józef Szujski podaje tu wlaściwic liczbę stron, a nic kart. Karty są bowiem paginowane, a nic foliowane, a jako żc podawane są tylko numery znajdujace się na stronach recto, więc ostatnią numerowana strona jest strona 587, w istocie jest oczywiście jeszcze s, 588.

${ }^{3}$ Codex epistolaris, s. LXII.

${ }^{4}$ Ibidem, s. 320 
paginowano strony i sporządzono wzmiankowaną notatkę oraz, co znamienne -w tych samych miejscach, gdzie profesor Szujski opuścił tekst rękopisu z powodu jego nieczytelności.

Trudno było ustalić dokładniejszą proweniencję rękopisu, ponieważ nigdzie nie ma na nim znaków własności: ekslibrisu, pieczęci, podpisu właściciela. Punktem wyjścia do zbadania historii kodeksu musiały więc być dane przekazane przez profesora Józefa Szujskiego. Rękopis pochodził z Biblioteki hrabiego Jerzego Szembeka z Poręby, z którym jak podaje Encyklopedia Kościelna Nowodworskiego, Szujski pozostawał w przyjaźni zarażając zamiłowaniem do zbierania materiałów źródłowych do historii Polski. Hrabia Szembek, w latach sześćdziesiątych i siedemdziesiątych XIX-go stulecia, nim przyjął święcenia kapłańskie, zajmował się studiami historyczno literackimi, a odziedziczywszy po dziadku Józefie Szembeku bogaty księgozbiór, sam również zdołał go pomnożyć cennymi nabytkamis. W księgozbiorze Szembeków znajdowały się głównie rzeczy dotyczące rodziny i przez jej członków napisane, ponadto wiele dzieł o tematyce religijnej, jako że wielu z nich było duchownymi i piastowali wysokie godności kościelne. Księgozbiór znacznie się poszerzył, gdy zakupiono w 1858 zbiory po wybitnym historyku, profesorze Józefie Muczkowskim. Dlatego wymaga jeszcze ustalenia, czy kodeks z listami Eneasza Sylwiusza znajdował się w bibliotece Szembeków jeszcze za czasów Józefa Szembeka, czy może dostał się tam ze zbiorami Józefa Muczkowskiego (które zawierały wiele cennych rękopisów historycznych), czy też Jerzy Szembek nabył go w czasie swoich osobistych poszukiwań. Wydaje się, że profesor Muczkowski tego kodeksu nie miał w swoich zbiorach we wczesnych latach pięćdziesiątych, ponieważ Maurycy Dzieduszycki, publikując $w$ latach 1853-1854 monografię o Zbigniewie Oleśnickim, nie miał dostępu do kodeksu, choć kilkakrotnie, co sam podkreślał, korzystał z rękopisów udostępnionych mu przez Józefa Muczkowskiego. Dowodem na to jest fakt, iż Dzieduszycki, publikując część listu Zbigniewa Oleśnickiego do Eneasza Sylwilusza z 10 września 1453 roku $^{6}$, znał go tylko z niepełnego odpisu rękopisów watykańskich, ze zbiorów zwanych Urbinates (nr rkp. 401 s. 9-15) oraz zbiorów Reginae Sueciae (nr rkp. 1878 od s. 1)7. Dzieduszycki dowiedział się o ich istnieniu dziçki informacjom przekazanym przez Aleksandra Przeździeckiego ${ }^{8}$, jednak osobiście tych rękopisów nie widział i polegał jedynie na cudzym odpisie ${ }^{9}$, pod-

${ }^{5}$ Zob. Encyklopedia kościelna, wyd. M. Nowodworski, t. 27, Warszawa 1904, s. 512.

${ }^{6}$ M. D zi ed us z y ck i, Zbigniew Oleśnicki, t. 2, dodatek XV, s. XXXI - XXXVI.

7 lbidem, s. 213-214.

${ }^{8} \Lambda$. Przeźdz i e c k i, Wiadomośc bibliograficzna o rękopismach zawierajacych w sobie rzeczy polskie przejrzanych po niektorvch bibliotekach i archiwach zagranicznych w latach 1846-1849, Warszawa 1850, s. 7 oraz 61 i 69.

${ }^{9}$ Potwicrdza to notaka w przypisic: ,Słowa antykwą drukowane nie znajdują się w Rękopiśmie Urbinates, wziął je więc zapewne przepisujący z lepszego kodeksu Reginac Sueciae”. D z i ed u szyck i, Zbigniew Oleśnicki, s. XXXII. 
czas gdy ten sam list znajduje się na pierwszych stronach kodeksu Szembeka. Co ciekawe odpis Dzieduszyckiego i list w kodeksie w pełni się pokrywają istnieją tylko drobne różnice $w$ końcówkach wyrazów, wynikające zapewne $z$ trudności w odczytaniu średniowiecznego pisma. A może odpis Dzieduszyckiego pochodził w istocie z kodeksu Szembeka, z pominięciem fragmentu dotyczącego kwestii literackich, dla historyka nieistotnych? Czyżby przepisującym był więc sam profesor Muczkowski, który udzielił Dzieduszyckiemu tylko odpisu bez podania jego pochodzenia, natomiast ten uznał, że jest to odpis z rękopisów watykańskich wzmiankowanych przez Aleksandra Przeździeckiego? Wyjaśnienie być może się znajdzie, gdy uda mi się dotrzeć do katalogu zbiorów Józefa Muczkowskiego znajdującego się w Bibliotece Jagiellońskiej.

Prawdopodobnie hrabia Jerzy Szembek udostępnił kodeks dla badań Józefa Szujskiego składając go w depozycie Biblioteki Akademii Umiejętności w Krakowie. Akademia Umiejętności patronowała bowiem serii Momumenta medii aevi historica, do której należy Codex epistolaris saeculi decimi quinti. W momencie wydawania pierwszego tomu, czyli w 1876 kodeks znajdował Bibliotece Akademii Umiejętności pod numerem depozytu 609. Jako depozyt, a nie własność Biblioteki, nie został tam opracowany, zatem nie uwzględniono go w Katalogu rękopisów Akademii Umiejętności w Krakowie Jana Czubka. Z dużym prawdopodobieństwem należy przypuszczać, że wkrótce potem został stamtąd zabrany przez właściciela, w roku 1879 Jerzy Szembek opuścił bowiem Kraków i udał się na Podole, w 1881 roku wyjechał do Włoch, po powrocie zaś zajął się zarządzaniem majatkiem rodowym i przebywał w swoich posiadłościach przez kilka następnych lat, po czym wstąpił do seminarium duchownego. W latach dziewięćdziesiatych, juz jako kapłan, przebywał w odległym Saratowie w diecezji tyraspolskiej. Nic zatem dziwnego, że Anatol Lewicki, wydając w roku 1894 trzeci tom Codex epistolaris, nie zdołał dotrzeć do oryginalnego rękopisu, skoro jego właściciel przebywał $\mathrm{z}$ dala od majątku w Porębie i trudno było by pytać go o zgodę. Skutkiem tego, rzekomy list Jana Hunyadego do sułtana tureckiego Omara, drukowany z kodeksu Szembeka, przekazano prawdopodobnie na podstawie notatek po zmarłym już wtedy profesorze Szujskim. Potwierdza to poniekąd sam Lewicki skarżąc się na brak możliwości skolacjonowania tekstu ${ }^{10}$. Dostęp do kodeksu miał jednak bezsprzecznie Ignacy Zarembski, który kilkakrotnie cytuje i powołuje się na niego w swojej rozprawie z 1939 roku pt. Stosunki Eneasza Sylwiusza z Polskq i Polakami" określając go jako kodeks hrabiego Szembeka z Poręby. Nie podaje innych danych o nim, wydaje się więc, iż kodeks był wtedy w bibliotece Szembeków $w$ Porębie. O tym zaś, że istotnie Zarębski miał w ręku oryginalny rękopis świadczy bezsprzecznie fakt, że korzystał z listów, które się w nim się znajdują, a które nie zostały opublikowane przez Szujskiego i Lewickiego, a także przez obcych

${ }^{10}$ Codex epistolaris saeculi decimi quinti, wyd. A. Lewicki, tom 3, w: Monumenta medii aevi historica, t. 14, Kraków 1894, s. 25.

"I. Z a ręb s k i, Stosunki Eneasza Sylwiusza z Polską i Polakami, Kraków 1939. 
wydawców korespondencji Eneasza Sylwiusza Piccolominiego - Georga Voita ${ }^{12}$ i Rudolfa Wolkana ${ }^{13}$. Zarębski powołuje się mianowicie na list Eneasza do Urlyka Sonnenberga nieznany nawet Voitowi i Wolkanowi, który w kodeksie Szembeka znajduje się na stronach 565-566, podaje też opuszczone przez Lewickiego fragmenty listu pisanego przez Eneasza w imieniu Hunyadego do sultana Omara ${ }^{14}$. I właśnie na podstawie cytowanego wyżej opisu kodeksu Szembeka podanego przez Józefa Szujskiego oraz wydanych w oparciu o niego listów w I i III tomie Codex epistolaris, jak i cytatów wykorzystanych przez Ignacego Zarębskiego z podaniem numerów stron, ponad wszelką wątpliwość można stwierdzić, że rękopis znajdujący się w Bibliotece KUL, to właśnie kodeks hrabiego Jerzego Szembeka z Poręby. Prawdopodobieństwo pomyłki należy wykluczyć, ponieważ nie ma możliwości, by istniały dwa kodeksy z takimi samymi listami Eneasza Sylwiusza znajdującymi się na tych samych stronach, tym bardziej, że paginowano reckopis zdefektowany, a ponadto w numeracji rçkopisu były dwie pomyłki. Gdyby istniały nawet dwa identyczne odpisy reckopiśmienne z tymi samymi listami, musiałyby posiadać inną liczbę stron i rozbieżną numerację, zestawiając zaś uzyskane informacje na temat kodeksu Szembeka z kodeksem Biblioteki KUL nie znaleziono żadnych niezgodności - numery stron, zawartość i opis rękopisu w pełni się pokrywają.

Nietrudno domyślić się, w jaki sposób rękopis trafił do zbiorów Biblioteki Uniwersyteckiej KUL. Jak podaje Janina Berger - Mayerowa „Biblioteka Szembeków z Poręby koło Alwerni pod Chrzanowem w ziemi krakowskiej została w czasie wojny, po wcieleniu tych terenów do Niemiec, częściowo zdewastowana przez hitlerowców i przewieziona na Śląsk. Zabezpieczona w pierwszym okresie po wojnie przez Zbiornicę Księgozbiorów Zabezpieczonych w Bytomiu, została następnie w tym samym stanie (bez katalogów i inwentarzy, i z licznymi defektami) przekazana Bibliotece Śląskiej w Katowicach, gdzie obecnie jest na nowo opracowywana"1s. Wśród zbiorów przekazanych Bibliotece Śląskiej nie było $\mathrm{z}$ pewnością dwóch piętnastowiecznych rękopisów należących wcześniej do Szembeków - omawianego w niniejszym artykule kodeksu z listami Eneasza Sylwiusza oraz niewielkiego, liczącego 17 kart, rękopisu wydanych w 1420 roku statutów synodalnych biskupa poznańskiego, Andrzeja Laskarego z Gosławic. Dla ścisłości należy dodać, że Biblioteka Szembeków posiadała trzy egzemplarze tych statutów, z których dwa były zszyte razem i znajdują się obecne w Bibliotece

${ }^{12}$ G. Voigt, Die Briefe des Aeneas Sylvius vor seiner Erhebung auf den päpstlichen Stuhl (dalej: Voigt), w: Archiv für Kunde österreichischer Geschichts-Quellen, Band 16, Wien 1856, s. $321-424$.

${ }^{13}$ Der Briefwechsel des Eneas Silvius Piccolomini herausgegeben von Rudolf Wolkan, Band 1-4 (dalcj: Wolkan), w: Fontes rerum Austriacarum - Österreichische Geschichts-Quellen, Abt 2 i 3, Band 61, 62, 67, 68, Wien 1909-1918.

${ }^{14} \mathrm{Z}$ a rę b s k i, Stosunki, s. 13-15, 67,75.

15 J. Berger-M a y r r w a, O Bibliotece Szembeków, „Sprawozdania Wroclawskiego Towa. rzystwa Naukowego", 11 (1956) seria A, s. 56. 
Śląskiej. Wszystkie uwzględnił profesor U. Heyzmann ogłaszając statuty biskupa Andrzeja Laskarego w Starodawnych prawa polskiego pomnikach ${ }^{16}$ oznaczając je jako kodeks S I i S II. Profesor Jakub Sawicki wydając w roku 1952 Synody diecezji poznańskiej $i$ ich statuty miał dostęp tylko do kodeksu S I znajdującego się w Katowicach, kodeks S II uważał zaś za zaginiony ${ }^{17}$. Wiadomość o tym, że rękopis ocalał i znajduje się w zbiorach Biblioteki Uniwersyteckiej KUL podała Helena Mańkowska w artykule Sekcja Rękopisów zamieszczonym w pracy zbiorowej z okazji jubileuszu działalności Biblioteki KUL ${ }^{18}$. Zasygnalizowała także, że rękopis pochodzi ze Zbiornicy Księgozbiorów Zabezpieczonych w Bytomiu, co również odnotowano w katalogu akcesyjnym sekcji rękopisów KUL ${ }^{19}$. W tej samej pracy zbiorowej Waldemar Michalski w artykule Oddzial gromadzenia i uzupelniania zbiorów w latach 1944-1970 informację tę niejako uzupełnił stwierdzajac, że w latach 1948-1953 Ministerstwo Oświaty nieodpłatnie przyznało Bibliotece KUL około 130 tys. wol. z magazynów tzw. Zbiornicy Księgozbiorów Zabezpieczonych. Prace nad wyborem i sprowadzaniem odpowiednich dla potrzeb Uniwersytetu dzieł ze Zbiornic w Bytomiu, Gliwicach, Katowicach i Wrocławiu prowadził o. dr Romuald Gustaw OFM, który w sierpniu 1950 objął stanowisko dyrcktora Biblioteki ${ }^{20}$. Prawdopodobnie zarówno kodeks z listami Eneasza Sylwiusza i statuty synodalne biskupa Laskarego zostały przywiezione z Bytomia do Biblioteki KUL około1950-1953, w każdym razie po sierpniu 1950 roku, gdyż w tym czasie profesor Andrzej Wojtkowski zakończył opracowanie wszystkich rękopisów znajdujących się wówczas w Bibliotece kończąc zapis inwentarzowy na sygnaturze 625. Gdyby rękopisy Szembeków już tam były, z pewnością nie zostałyby pominięte. Akta synodalne zostały wpisane tylko do katalogu tzw. tymczasowego, czyli akcesyjnego, który zaczęto prowadzić od 1965, listy Eneasza Sylwiusza pozostawały natomiast w zbiorach nieopracowanych aż do 2003 roku. Co ciekawe, oba rękopisy maja na wewnętrznej stronie oprawy notatki w języku niemieckim sporządzone tą samą ręką, w których zaznaczono orientacyjny czas ich powstania i czego dotycza.

Ze względu na fakt, że profesor Szujski przekazał tylko ogólne informacje na temat kodeksu i dotąd nie został on szczególowo omówiony w żadnej publikacji, postaram się wiadomości o nim uzupełnić.

Rękopis składa się z 32 składek papierowych in 4-to. Są to w większości kwinterniony, jest kilka seksternionów i jeden okternion.

"Statuta synodalia Andreae, episcopi poznanensis saeculo XV" confecta, w: Starodawne prawa polskiego pomniki, t. 5, Suplementum, Cracoviae, 1877, s. [-XL.

${ }^{17}$ J. S a w i c k i, Synody diecezji poznaniskiej $i$ ich statuty, w: Concilia Poloniae, t. 7, Poznań 1952, s. 8-9.

${ }^{18}$ H. M a ń k o w s k a, Sekcja Rękopisów, w: Biblioteka Uniwersytecka Katolickiego Uniwersytetu Lubelskiego 1918-1970, „Archiwa, Biblioleki i Muzea Kościelne”, 23 (1971) s. 145 [129].

${ }^{19}$ Rękopis w katalogu akcesyjnym oznaczony jest sygnaturą 109.

${ }^{20} \mathrm{~W}$. M i chalsk i, Oddzial gromadzenia i uzupelniania zbiorów w latach 1944-1970, w: Biblioteka Katolickiego, s. 72 [56]. 
1. s. 1-22-seksternion [brak 1 karty pos. 4 i 1 karty po s. 20 , s. 21-22 niezapisane

2. s. 23-36 - kwinternion [brak 3 kart po s. 28]

3. s. 37-54-kwinternion [zachowany w całości, s. 50-54 niezapisane]

4. s. 55-70 - seksternion [po s. 68 brak dwóch kart, także po s. 70 brak dwóch kart]

5. s. 71-80 - kwinternion [brak 2 kart po s. 78 , brak 3 kart po s. 80]

6. s. 81-98 - kwinternion [brak 1 karty przed s. 81 , brak 4 kart po s. 88 , s. $87-88$ i 97-98 - niezapisane, prawdopodobnie brakujące 4 karty byly także niezapisane]

7. s. 99-112 - kwinternion [1 dodatkowa karta została wyrwana przed s. 99, brak 3 kart po s. 110]

8. s. 113-126 - kwinternion [brak 1 karty po s. 118, brak 2 kart po s. 126]

9. s. 127-138 - kwinternion [przed s. 127 brak 3 kart, po s. 138 brak 1 karty]

10. s. $139-150$ - kwinternion [brak 2 kart przed s. 139 , po s. 140 brak 2 kart]

11. s. 151-170-kwinternion [zachowany w całości]

12. s. 171-188-kwinternion [brak 1 karty po s. 188]

13. s. 189-200 - kwinternion [brak 4 kart po s. 200]

14. s. 201-214-kwinternion [brak 1 karty przed s. 201]

15. s. 215-234-kwinternion [zachowany w całości]

16. s. 235-254-kwinternion [zachowany w calości]

17. s. $255-274-\mathrm{kwinternion} \mathrm{[zachowany} \mathrm{w} \mathrm{całości]}$

18. s. 275-282 - 1/2 kwinternionu [po s. 280 brak 1 karty, s. 281-282 - niezapisane

19. s. 283-304 - seksternion [brak 1 karty po s. 290]

20. s. 305-328 - seksternion [zachowany w całości]

21. s. 329-344 - seksternion [brak 1 karty przed s. 329,2 kart po s. 338 brak 2 kart po s. 338 , brak 1 karty po s. 340,1 karty po s. 344]

22. s. 345-362 - kwinternion [brak 1 karty po s. 358]

23. s. 363-378 - kwinternion [brak 2 kart przed s. 363 , ale nie ma po nich śladu, s. 368-378 - niezapisane]

24. s. 379-402 - seksternion [zachowany w całości, s. 397-402-niezapisane]

25. s. 403-424 - seksternion [dodatkowa 1 karta - składka liczyła 13 kart, brak 2 kart po s. 410$]$

26. s. 425-448 - seksternion [zachowany w całości]

27. s. 449-470 - seksternion [brak 1 karty po s. po s. 452]

28. s. 471-492 - seksternion [brak 1 karty po s. 492]

29. s. 493-510 - seksternion [bez 1 karty- składka liczyła 11 kart, przed s. 493 brak 1 karty]

30. s. 511-542 - okternion [zachowany w całości] 
31. s. 543-566 - seksternion [zachowany w całości]

32. s. 567-588 - kwinternion [zachowany w całości, dodatkowo 5 niezapisanych kart na końcu rękopisu].

Poza wymienionymi powyżej miejscami, gdzie widać ślady po wyrwaniu całych kart, kodeks posiada równiez defekty w postaci uciçtych i udartych w połowie lub w części kart, gdzie tekst nie zachował się w całości. Są to: s. 33, 37 [1 linijka u dołu], s. 113 [2 linijki u dołu], s. 137 [połowa karty], s. 139 [1linijka u dołu], s. 141 [1 linijka u góry], s. 163 [kilka linijek u dołu], s. 219, 291 [1 linijka u dołu], s. 411, 413 [duży ubytek tekstu - karty udarte ukośnie], s. 449, 451, 453, 455, 457 [ udarte u dołu od kilku linijek do połowy karty], s. 359 [karta przecięta na marginesie, ale tekst nie został uszkodzony].

Pismo: kursywa gotycka oraz kursywa humanistyczna $z$ drugiej połowy wieku XV kilku rąk.

Ręka A: Dukt 1 niezwykle staranna, kaligraficzna włoska kursywa humanistyczna. Pismo to jest dość duże, równe, cieniutkie, subtelne, ozdobne. Potwierdza ono obce pochodzenie kodeksu, a w każdym razie tych jego części, które je zawieraja. Sa to składki: 2, 3, 7, 8, 9, 10, 11, 12, 15, 16, 17, 18 [s. 23-49, 99-188, 215-280]. Dukt 2 - pismo bardzo staranne, niezbyt grube, ozdobne, równe, duże, okragłe litery linia pióra dość cienka i niezróżnicowana. Jest to kaligraficzna włoska minuskuła humanistyczna z elementami stylu gotyckiego podobna do druku. Składka 24 [s. 379-396].

Ręka B: Umownie przyjmijmy wymienione poniżej dziesięć różnych duktów jako ,rękę B", gdyż trudno z całą pewnością stwierdzić, że wszystkie wymienione poniżej charaktery pisma są dziełem jednej tylko ręki. Być może w przepisywaniu listów i mów brało udział jeszcze dwóch lub więcej kopistów. Nie można też wykluczyć, że był on tylko jeden, lecz pisał w pewnych odstępach czasu, piórami o różnej grubości, różnymi rodzajami inkaustu, co wymagało zastosowania różnych duktów pisma. Dukt 1 - pismo gęste, okrągłe, niewysokie, grube, mało wyraźne, ale staranne, równe - jest to kursywa gotycka, jest nia pisana składka 1 i 4 [s. 1-20, 55-70]. Składka 4 bardziej staranna i czytelna. Dukt 2 - pismo bardzo staranne, równe, okragłe i szerokie litery, gruba linia pióra, kaligraficzna kursywa gotycka z elementami stylu humanistycznego. Składka 5 i część składki 30 [s. 71-80, 511-516, 523-530, 537-541]. W składce 30 delikatniejsza linia pióra, lekko cieniowana, bardzo staranna, kaligraficzny gotyk, miejscami ozdobny. Dukt 3 - pismo staranne, bardzo gęste, literki okragłe, drobne, cienka linia pióra, małe odstępy między wersami, literami i wyrazami, zamaszysty charakter pisma. Jest to kursywa humanistyczna z elementami gotyku. Składka 19 [s. 283-304]. Dukt 4 - pismo niestaranne, zamaszyste, litery niezbyt duże, często rozstrzelony tekst, duże i nierówne przerwy między literami, wyrazami i wersami, linia pióra średnio gruba, cieniowana, dużo abrewiacji, mało przejrzysty tekst, trudny do odczytania. Składka 20, 12 ostatnich wersów składki 27, składka 28, 29 [s. 305-328, 1/3 s. 470, s. 471-510]. Dukt 5-pismo drobne, mało staranne, niezbyt wyraźne, gęste, z licznymi abrewiacjami, minuskuła gotycka. Składka: 21, 
22, 23 [s. 329-367]. Dukt 6 - kursywa gotycka, pismo rozstrzelone, mało staranne, podobne jak dukt 2 , ale mniej staranne, inna linia pióra, grubsza, bardziej jednolita, niecieniowana, użyto tu inny, znacznie jaśniejszy inkaust, niż w dukcie 2. Składka 26 [s. 425-448]. Dukt 7 - kursywa gotycka, pismo niezbyt staranne, bardzo gęste, nierówne, litery dość duże, wysokie i zaokraglone, linia pióra zamaszysta, cieniowana, lekko zdobiona, inkaust ciemniejszy, niż w poprzednim dukcie. Składka 27 [s. 449-470 - bez 12 ostatnich wersów strony 470]. Dukt 8 - pismo bardzo staranne, delikatnie zdobione, rozwlekłe, z dużymi odstępami między literami, wyrazami, wierszami. Miękka, zamaszysta linia pióra, delikatnie cieniowana - jest to kursywa humanistyczna. Część składki 30 [s. 517-522, 531536]. Dukt 9 - pismo staranne, lekko zdobione, litery duże, okragłe, wyraźne, linia pióra dużo grubsza niż poprzednia, niecieniowana. Jest to kursywa humanistyczna z elementami gotyku. Składka 31 [s. 543-566]. Dukt 10 - pismo bardzo staranne, litery okragłe, duże, ozdobne, estetyczne, bardzo łatwe do odczytania, linia pióra starannie cieniowana, pewne czçści liter bardzo cienkie, inne grubsze - kursywa humanistyczna z elementami gotyckimi przypominająca włoskie pismo kancelaryjne. Składka 32 [s. 567-588].

Ręka C: pisıno cienkie, wąskie z „wywijasami”, bardzo gęste, drobne literki, dość wysokie, dużo abrewiacji - kursywa humanistyczna, ale mało wyraźna i mato staranna. Składka 6, 13, 14, 25 [s. 81-86, 189-214, 403-424].

$\mathrm{Z}$ pewnością przynajmniej część kodeksu ma pochodzenie obce, trudno to ustalić, ponieważ żaden $\mathrm{z}$ kopistów nie podał swego imienia, a ponadto papier jest złożony $w$ ten sposób, że nie widać w całości nawet jednego znaku wodnego, na podstawie zaś fragmentów, nie pokuszę się o ich identyfikowanie. $Z$ widocznych fragmentów można przypuszczać, że przynajmniej niektóre składki papieru pochodza z papierni wiedeńskich z drugiej polowy XV stulecia. Wydaje się, że najstarsze części kodeksu, to składki z pismem włoskim [ręka A], które bądź z powodu uszkodzenia czy też zagubienia nie przekazały pełnej treści listów i mów Eneasza, zostały więc uzupełnione przez innych kopistów [ręka $\mathrm{B}$ i C]. Potwierdzeniem tego jest między innymi fakt, że na s. 23 nagłówek listu i początkowe dwie linijki zostały dopisane kursywą gotycką przez kopistę $\mathrm{B}$ do pisma włoskiego. Kopista $\mathrm{C}$ prawdopodobnie złożył i zredagował kodeks, o czym świadczą sporządzone przez niego reklamanty - np. na s. 49 z pismem włoskim rysuje mała gwiazdkę z uwaga,, signum tale vide” i ta sama gwiazdka pojawia się na s. 55, gdzie jest dalsza część listu ze strony 49, pisana jednak przez kopistę B kursywa gotycka. Podobnie na stronie 211, gdzie jest tekst pisany przez tegoż kopistę i na końcu uwaga: ,in alio quinternio tale signum" [kółko z poprzecznym krzyżykiem] i znak ten pojawia się na s. 215 z pismem włoskim. Jego ręką sa napisane również Lodovicus in alio sexternione (s. 424) i fundique (s. 448) oraz nieliczne w tym rękopisie glosy, między innymi na s. 312, 217, 324, 326, 339, 348, $460,461,471$. Niekiedy widoczne są też jego poprawki, uzupełnienia i rozwiązania zbyt mało czytelnych skrótów. Można je znaleźć właś-ciwie we wszystkich 
odpisach z tym, że w składkach pisanych pismem włoskim pojawiają się bardzo rzadko, natomiast bardzo często w skladkach z niestaranną kursywa gotycka.

Treść rękopisu właściwie w całości dotyczy działalności dyplomatycznej Eneasza Sylwiusza Piccolominiego z lat 1443-1455. Są to listy prywatne i urzędowe pisane przez niego i do niego adresowane oraz mowy wygłoszone $w$ czasie istotnych wydarzeń politycznych. Oprócz mów Eneasza jest też kilka mów Jana de Castilonio, biskupa Pawii, legata papieskiego na sejmach w Ratyzbonie i Frankfurcie (1454), oraz dwie mowy Jánosa Vitéza, biskupa waradyńskiego, kanclerza Węgier i jedną mowę Wilhelma, biskupa Tulonu. Pozostają one jednak w ścisłym związku z działalnością Eneasza, były one bowiem wygłoszone w czasie, gdy Eneasz również wypowiadał się w tych samych kwestiach na sejmach w Ratyzbonie, Frankfurcie i Neustadt. Można zauważyć, iż poszczególne składki zawierają listy i mowy zbliżone do siebie w czasie. I tak składka 1 zawiera korespondencję Eneasza z lat 1450-1453, składka 2 list oraz mowy wygłoszone w 1451, 3 składka zawiera listy urzędowe pisane przez Eneasza w imieniu cesarza Fryderyka III w 1454 na temat konwentu w Ratyzbonie powołanego w celu zorganizowania krucjaty przeciwko Turkom. Składka 4 uzupełnia tą korespondencję urzędową $\mathrm{z}$ roku 1454 pisaną $w$ imieniu cesarza i własnym, zawiera też listy z roku 1453 oraz jeden list z 1451. Składka 5 zawiera listy z roku 1449, kiedy Eneasz był biskupem Triestu. Składka 6 uzupełnia list z poprzedniej składki oraz zawiera jeszcze jeden z tego samego roku - 1449. Składka 7 pisana włoska kursywa humanistyczną podobnie jak składka 3, zawiera jeden list Alfonsa Aragońskiego z roku 1454, oraz część listu Eneasza do Zygmunta, władcy Austrii z roku 1443 (jest to jeden $z$ wcześniejszych listów w kodeksie Szembeka, tutaj jednak niedatowany). W składce 8 znajduje się ciąg dalszy tegoż listu oraz część listu Eneasza do Prokopa de Rabenstein z 1444 roku, w składce 9 kontynuacja listu do Prokopa i dwa listy z 1445 i 1446 roku. Składka 10, 11 i 12 zawierają mowę Jana de Castilonio, legata papieskiego na sejmie we Frankfurcie w październiku 1454 roku, mająca zachęcić i zmobilizować cale chrześcijaństwo Europy do skutecznej walki z Turkami. Składka 13 zawiera po jednym liście z 1444, z 1443, 1446 i 1448 roku. Składka 14 zawiera część mowy Eneasza Sylwiusza zachęcającej do wojny z Turkami, wygłoszonej na konwencie frankfurckim w październiku 1454 roku, brak początku mowy, który znajdował prawdopodobnie na wyrwanych kartkach tej, a może również poprzedniej składki. Mowa nie jest przepisana do końca, a tylko do słów, którymi rozpoczyna się pozostała cześć mowy pisana pismem włoskim w składce 15, w składce 14 jest jeszcze list do papieża Mikołaja V napisany w czasie tego konwentu. Składka 15 oprócz końcówki mowy Eneasza zawiera także początek mowy Wilhelma, biskupa Tulonu, legata Filipa, księcia Burgundii na konwencie frankfurckim. Składka 16 zawiera dokończenie mowy biskupa Wilhelma oraz ogólne ustalenia konwentu frankfurckiego i listę obecnych na sejmie frankfurckim posłów i ambasadorów państw i księstw mających wziąc udział w krucjacie, a także sposoby uzyskania funduszy na tę wyprawę. Składka 17 i 18 
zawiera mowę Jánosa Vitéza, biskupa Waradynu, kanclerza Węgier i przedstawiciela delegacji wegierskiej na sejmie Neustadt 23 marca 1455. Składka 19 zawiera mowę Jana de Castilonio, legata papieskiego wygłoszoną do cesarza Fryderyka na sejmie w Ratyzbonie w maju 1454 oraz mowa tegoż do króla Węgier, Władysława Pogrobowca, także w czasie trwania konwentu w Ratyzbonie. W składce 20 znajduje się niepełna mowa Jana de Castilonio przed panami węgierskimi w Ratyzbonie, której dokończenie jest w składce 21 , gdzie również znajduje się skierowana do ogółu mowa zachęcająca do wspólnej krucjaty oraz początek mowy o podobnej treści wygłoszonej na konwencie frankfurckim w październiku 1454 roku. W składce 22 jest dokończenie tejże mowy oraz początek Eneaszowego traktatu na temat problemów literackich pochodzący prawdopodobnie także $z$ roku 1454 oraz kilka listów bez datacji, a niekiedy nawet bez nadawcy i adresata, które jednak udało się zidentyfikować na podstawie edycji Wolkana jako listy z lat 1431, $1432,1442,1443 \mathrm{i} 1444$ roku - są to w kodeksie listy pochodzace $\mathrm{z}$ najwcześniejszego okresu życia i działalności Eneasza Sylwiusza. Składka 23 to kilka listów Eneasza bez datacji zidentyfikowane jako dwa listy z 1443 i jeden z 1444 roku. Składka 24 zawiera odpowiedź Eneasza daną posłom węgierskim po przemówieniu biskupa waradyńskiego, wygloszoną 23 marca 1455 roku w Neuestadt. Skladka 25, 26, 27, 28 i 29 zawierają odpowiedź Eneasza daną także Jánosowi Vitézowi, ale na sejmie Ratyzbonie w maju 1454 roku. Składka 30 zawiera mowę Eneasza wygłoszoną $z$ okazji zaręczyn Fryderyka III z Eleonorą portugalską w Neapolu 11 grudnia 1450 roku oraz mowę Eneasza przed papieżem Mikołajem V w sprawie koronacji Fryderyka na cesarza w Rzymie wygłoszoną w 1451 roku. Składka 31 zawiera 12 listów Eneasza pisanych w czasie, gdy był on biskupem Tricstu, głównie z roku 1449, ale są też dwa z roku 1448 i jeden z 1447 roku. Składka 32 zawiera jeden list z 1449 roku i dwa z roku 1451.

$A$ oto jak szczegółowo przedstawia się treść rękopisu (incipit i explicit rozdzielone pauza):

1. Sbigneus miseratione divina S. R. Ecclesiae tituli S. Priscae presbyter cardinalis ac episcopus Cracoviensis, reverendo in Christo Patri domino Aeneae episcopo Senensi et imperiali consilario, amico suo singulari - Ex Cracovia, decima septembris 1453 , s. 1-10.

Drukowany fragmentarycznie przez Dzieduszyckiego ${ }^{21}$, w calości w' Codex epistolaris ${ }^{22}$. W rękopisie brakuje s. 5 i 6 od stów , sanctae, clero et toti christianissimo populo" do, debito honore exceptum".

2. Integerrimo sanctoque patri suo, Iohamni episcopo Eystetensi [Jan Aich],

${ }^{21}$ D zieduszy cki, Zbigniew Oleśnicki, s. XXXI-XXXVI.

${ }^{22}$ Codex epstolaris, t. 1, s. 315-320. Za nim Voigt nr 273, Wolkan IV nr 137, s. 245 --253. Wolkan przyznaje, że korzysta z Codex epistolaris' i wymicnia kodeks Szcmbeka jako jego źródło s. 245. 
domino et consacerdoti suo, Aeneas, episcopus Tergestinus - Ex Nova civitate, 10 kalendas augusti 1450, s.11-1223.

3. Venerabilis amice carissime - Ex Vienna, 16 iunii 1451 List Aeneasza Sylwiusza do pewnego przyjaciela, s. 12-1324.

4. Moderato et praestabili viro Nicolao secretario imperiali [secretario civitatis Hesselinge] Aeneas episcopus Senensis — vale, s. 13-14 $4^{25}$.

5. Dionisio sanctae Romanae Ecclesiae cardinali archiepiscopo Strigoniensi [Dionizjusz Szécsy], patri et domino colendissimo, Aeneas Silvius, Senensis episcopus ${ }^{26}$ - expedit regno, s. 14-20.

List w rękopisie kończy się stowami "expedit regno" - brak polowy listu, slad po wyrwaniu kart ${ }^{27}$.

6. Aeneas dei gratia episcopus Senensis, domino Iohanni Hinderbachio, secretario regio et amantissimo fratri - veniam postulasset, s. 23-28.

Wrekopisie brak polowy listu, który urywa się na slowach „veniam postulasset" [list ex Vienna, kalendis iuniis 1451$]^{28}$.

7. Oratio habita per dominum Aeneam Silvium coram Regem Portugaliae - manifestius serveris, s. 29-31

Poselstwo Eneasza Sylwiusza w imieniu cesarza Fryderyka z prośbq o rękę Eleonory, siostry króla Portugalii i Aragonii, Alfonsa. Mowe można datować na ok. 1451, gdyż Fryderyk III wzial ślub z Eleonorq 1 VIII 145I roku w Lizbonie, potwierdzono go w Rzymie wraz z koronacja cesarska 16 III 1452.

8. Ad sponsam - petitum nequeat impetrari, s. 31-32-ok. I451 roku.

9. In contractu matrimonii - senibus supervivant. Finis, s. 32-35 - ok. 1451 roku.

10. Fridericus imperator divina favente clementia Romanorum imperator semper Augustus serenissimo principi Alfonso, regi Aragonorum ac Siviliae - Ex Gretz 1453, s. 36-38, 38a oraz 38b.

W liście tym Fryderyk III pisze o majacym się wkrótce odbyć konwencie w Ratyzbonie, w maju 1454 - na świętego Grzegorza, na którym maja być obecni legaci Alfonsa i rozumie, że on sam nie będzie mógt przybyć. Zawiadamia go, że jego malżonka, a zarazem siostra Alfonsa, jest w szóstym miesiqcu ciqzy. Martwi sie

${ }^{23}$ Voigt, ur 185, Wolkan III nr 43, s. 162-163.

${ }^{24}$ Voigt, nr 189, Wolkan IV nr 7, s. 17-18.

${ }^{25}$ Wydanic bazylejskie ep. 119, s. 646 - nie podaje daty, Voigt, nr 191, Wolkan IV, nr 47 s. 98 -101 - datuje ex Vienna circa iulii 1452.

${ }^{26}$ Tu błędnie kopista podał „Senensis episcopus”, ponieważ list ten powstał, jak podaje Rudolf Wolkan (Wolkan I nr 189, s. 548), na początku października 1445 roku. Wtedy Eneasz był sekretarzem Fryderyka III, biskupem Sieny został został dopiero w 1450. Na czas przyjcty przez Wolkana wskazywałaby treść listu - po konwencie w Peszcie, gdzic Węrzy, straciwszy króla Władysława w klęsce warneńskiej, obrali królem Władysława Pogrobowca i zaczęli układać sic̨ z Fryderykiem o zwrot małoletniego króla i korony świętego Stefana.

${ }^{27}$ Wyd, bazyl. ep. 78, Voigt, nr 158; Wolkan I, nr 189, s. 548-558.

${ }^{28}$ Wyd. norymb. 126, bazyl. ep. 126, Voigt, nr 187; Wolkan IV, nr 5, s, 10-16. 
o konflikt Alfonsa z Florencja i innymi państwami wloskimi, co grozi wojna ${ }^{29}$. List można datować na koniec 1453 roku, jeśli wierzyć datacji podanej przez kopistę, ale może to być również poczatek 1454 roku.

11. Fridericus divina favente clementia Romanorum imperator semper Augustus serenissimo principi Carolo, dei gratia Regi Francorum, fratri nostro carissimo salutem et amoris fraterni totissimum merementum - Ex Nova civitate 1454 , s. 38b-47.

List Fryderyka III do króla Francji, Karola, w którym pisze o poselstwie legata papieskiego Jana de Castilonio i jego poruszajacej mowie zachecajacej do walki z Turkami. Mówi o majacym wkrótce się odbyć konwencie w Ratyzbonie i prosi Karola o wyslanie tam poselstwa ${ }^{30}$.

12. Friddericus serenissimo [Alfonso] regi Aragonorum. Superioribus diebus, quibus apud civitatem nostram Ratisponam in festo sancti Gregorii - Ex Nova civitate 1454, s. 47-49 oraz s. 55.

Cesarz Fryderyk ustala konwent w Norymberdze, na święto Michala, na kiórym maja zamiar ustalić wystanie floty z Italii do Hellesponiu w celu zatrzymania wojsk tureckich $w$ Azji, dlatego zaleca Alfonsowi pokój z Wenecjq. Kończy list prośbq o poslów z pelnymi kompetencjami na nowy konwent i ma nadzieje, że Alfons wystawi wojsko wraz z Wenecjq ${ }^{31}$. Wkrótce po konwencie w Ratyzbonie 1454. List pisany przez dwóch kopistów - pierwszy s. 47-49 konczy slowami „populi Christiani", drugi kopista kończy lenże list na s. 55 rozpoczynajac od slów ,, totius populi Christiani".

13. Friddericus imperator regio fratre [Carolo].Vulnere quod impetus Turchorum oppugnata Constantinopoli ortodoxa fidei consilio - Ex Nova civitate 21 iunii 1454 s. 55-57.

Prosi, aby Karol wystat swoich poslów z pelnomocnictwem na konwent w Norymberdze na świętego Michala 1454 roku ${ }^{32}$.

14. Domino policito Urlico Riederer, perspicati et merementi iuris consulto ac senatore caesareo, Aeneas episcopus Senensis - Ex Nova civitate 1454 s. $57-58^{33}$.

15. Reverendo in Christo patri, Iohanni de Capistrano ordinis minoris professori ac vicario generali Aeneas episcopus Senensis - Ex Nova civitate die V iulii 1451 s. 59-60.

Ten sam list występuje tez na końcu rękopisu, lecz sporzqdzony jest ręka innego kopisty. List Eneasza Sylwiusza do Jana Kapistrana w czasie jego pobytu w Wiedniu. Kapistran udal się tam w czerwcu na zaproszenie Fryderyka III,

${ }^{29}$ Wolkan IV, nr XIJ, s. 593-595. Gretz [Graz] - konicc octobris 1453 lub początek roku 1454.

${ }^{30}$ Wolkan IV, nr XIV, s. 602-606. Wolkan podaje dokładniejszą datę-datum in Nova civitate die mensis ianuarii imperii nostri anno secundo 1454.

3 Nieznany Voigtowi, nie ma go teź w edycji Wolkana.

${ }^{32}$ Nie ma u Voigta i Wolkana.

${ }^{33}$ Wolkan IV, nr 209 s. 396-397 (tylko na podsławie rękopisów, gdzie indziej niepublikowany). 
klóry właśnie za rada Eneasza Sy/wiusza poprosil papieża Mikolaja V, by przyslal go do Wiednia, gdzie Kapistran przebywat do końca lipca. W liście tym Eneasz dziękuje za jego przybycie i zaprasza na dwór cesarski do Neustadt ${ }^{34}$.

16. Reverendo in Christo domino Nicolao [Mikołaj z Kuzy], sanctissimae Romanae ecclesiae tituli sancti Petri ad vincula cardinali, domino suo colendissimo Aeneas episcopus Senensis - Ex Gretz 1453, s. 60-61. List Eneasza Sylwiusza do Mikolaja z Kuzy, w którym mówi o sprawie Wladystaw'a Pogrobowca i jego opiekuna hr. Urlyka Cilly ${ }^{35}$.

17. Fridericus divina favente Romanorum imperator serenissimo principi Alfonso, Dei gratia regi Portugaliae et Aragoniae — datum, s. 61-63.

Fryderyk zapewnia szwagra o swojej olbrzymiej milości względem swojej malżonki, a jego siostry. Jest to odpowiedź na list Alfonsa do Fryderyka, w kiórym ten dziękuje za wielka milość cesarza do jego siostry i prosi, aby byta ona jeszcze większa i trwala. Prawdopodobnie oba listy w podtekście dotycza niewyrażonego expressis verbis niepokoju i zniecierpliwienia cesarza z powodu niklych, jak mu sie zdawalo, nadziei na potomstwo. List Alfonsa w dyplomalyczny sposób przypominat Fryderykowi jego zobowiqzania matzeniskie i jednocześnie wyraża wiare, iż cesarz przez wzglad na milość do malżonki nie zdecyduje sie jej odeslać lub anulowac malienistwa, stad te gorace zapewnienia cesarza ${ }^{36}$. Dowodem na to, że problem istnial, jest późniejszy o kilka miesiçcy [z końca 1453 lub początku $1454]$ list Fryderyka do Alfonsa, w którym donosi, że Eleonora, jest już w szóstym miesiqu ciqży, choć weześniej male davala mu nadzieje na potomstwo ${ }^{37}$.

18. Beatissime pater et domine - Datum in Nova civitate XII octobri 1453 [Fridericus ad Nicolaum V], s. 63-65.

19. Fridericus imperator [Aeneae Silvio?]. Reverendissime pater, amice mi carissime - possumus et acceptum, s. 65-66.

Okolo 1753-1454 roku.

20. Aeneas. Reverendissime in Christo pater et domine mi colendissime Vilhelmus, episcopus Thulensis. Ulricum Sillacei, comitem magnum et potentem virum, qui regem Hungariae et Bohemiae Wladislaum gubernabat - in Austria ad Novam civitatem suaderet ${ }^{39}$, s. 66-70.

\footnotetext{
${ }^{34}$ Wolkan IV, nr 9, s. 19-20.
}

${ }^{35}$ Ze względu na ograniczony czas dostçpu do IV tomu edycji Wolkana (dostepncgo tylko w Bibliotece Jagicllonskicj), nie zdolatam sprawdzic, czy ten list jest tam zamieszezony, ponicważ próba wypożyczenia międzybibliotecznego się nie powiodła.

${ }^{36}$ List Alfonsa, jak podaje Wolkan, nosi datę: Ex civitate nostra Elborensi 25 martii 1453. Odpowiedź Fryderyka wysłano z Graz 28 IX 1453 (w kodeksic Szcmbeka brak daty). Wolkan IV, nI IX - publikuje te listy tylko na podstawie rękopisów, tak wį̨e niniejszego listu nic publikowano nigdzie indzicj.

${ }^{37}$ Kodeks Szembeka, s. 38.

${ }^{38}$ Wolkan IV, nr X, s. 588-592 (publikuje tylko na podstavie rękopisów).

${ }^{39}$ Nicznany Voigtowi i Wolkanowi. 
Trudno ustalić datę, brak końca listu, w rękopisie nie ma w tym miejscu jednej kartki.

21. ...duo scriptores diversas Iordani origines, quamvis contrarii videantur a vero - Vale ut optas ex Nova civitate Austriae III kalend. martii 1449, s. $71-74^{40}$.

Brak poczqtku listu, prawdopodobnie Eneasza do nieustalonego odbiorcy.

22. Aeneas, episcopus Tergestinus iuris consultissimo viro domino Gregorio Hamburgensi - Ex Nova civitate kalendis februariis $1449^{41}$.

23. Venerandissimo sanctoque patri, domino Iohanni Carvaiali, sacrosanctae Romanae Ecclesiae diacono cardinali, Aeneas episcopus Tergestinus - Ex Laibaco die XIII octobris $1449^{42}$, s. 77-80.

Wrękopisie list ten kończy się na slowach Philipus Maria [Wolkan s. 89], następnie brakuje dwóch kart rękopisu, zachowata się zaś ostatnia karta listu rozpoczynajaca się stowem iniquitates [Wolkan, s. 927 ${ }^{43}$. Na stronach 81-85 rękopisu znajduje się ten sam list do Carvaiala, przepisany przez innego kopiste, brakuje tylko kilku poczqukowych zdan, tekst rozpoczyna sie slowami "si mihi defueris" [Wolkan, s. 887 i do końca listu niczego nie brakuje.

24. Revercndissimo in Christo sanctoque patri, domino Nicolao de Cusa [Mikołaj z Kuzy], sacrosanctae Romanae Ecclesiae praesbytero cardinalique Aeneas episcopus Tergestinus - Ex Nova civitate XVI kalendas aprilis 1449 , s. 85-8644.

25. Epistola serenissimi domini Alfonsi, regis Aragonorum etc. sacro collegio cardinalium sanctae romanae ecclesiae - Data in castro novo Neapol prima aprilis 1454 , s. $99-103^{45}$.

26. Illustrissimo principi et ex sanguine caesarea sancto domino Sigismundo Austriae duci Aeneas Silvius regalisq secretarius - caesar permittit tuum habeto. Finis, s. 103-122.

Defekt, brak części listu od stów "qui superioribus saeculis" do „in senectute Cicero" - wyrwane trzy karly, ponadto brak czésci listu od stów , quia iuvenes" do "qui perdita" - wyrwana jedna kartka ${ }^{46}$.

27. Aeneaes Silvius poeta domino Procopio de Rebenstein militi literato et praestanti - Ex Vienna VI kalendas iulii anno $1444^{47}$, s.123-133.

Defekt - brak pięciu kart od slów „pontificis mihi gratiam” do „animi eum sequitur".

${ }^{40} \mathrm{Nic}$ ma w edycji Wolkana.

"Wydanic bazyl. ep. 120 (nic podaje roku), Voigt ur 182, Wolkan IIl nr 25, s. 79-81 (datowany pridie kalendas februarii 1449).

${ }^{42}$ Voigt, nr 184, Wolkan III nr 31, s. 88-93.

${ }^{43}$ W kodeksie Szembeka jest tak, jak u Wolkana-octobris, natomiast u Voigta jest novesnbris.

H Wolkan III, nr 28, s. 85-w datacji podaje tylko ex A. 1449.

45 Wyd. norym nr 139, bazyl. 139, Voigt, nr 261. Wolkan IV, nr 125.

$46 \mathrm{~W}_{\text {yd }}$. bazyl. ep. 105, Voigt, nr 71; Wolkan I, nr 99, s, 222-236. Wolkan datuje: ex Gretz, nonis decembris anno 1443.

${ }^{17}$ Wyd. bazyl, ep. 108, Voigt, nr 118; Wolkan I, nr 151, s. 343-353. 
28. Reverendissimo in Christo patri et illustri principi domino Iohanni [de Aich], episcopo Eystetensis, domino suo primori Aeneas Silvius imperialis secretarius - Ex Vienna kalendis ianuarii $1446^{48}$, s. 134-136.

29. Doctissimo oratori et poetae domino Aeneae Silvio Senensi, regio secretario Iohannes Campisius. Periocunda mihi sint lectio tuarum litterarum, quas novissime ad me dedisti - Nonnulli quoque ex famulis eiusdem patris decessere, s. 137-138.

Brak końca listu - jedna karta udarta w polowie, brak trzech (lub czterech) kart. Koniec września $1445 r^{49}$

30. ... maxime opportunarum - Qui est benedictus in saecula saeculorum. Amen, s. 139-188

[Oratio Iohannis de Castilonio, legati apostolici, episcopi papiensi, coram Fridericum, imperatorem Romanorum in Francofordia, mensis octobris $\left.1454^{50}\right]$.

Brak poczqtku mowy.

31. Aeneas Silvius poeta domino Vilhelmo de Lapide militi literato et strenuo — Ex Vienna, kalendis iunii 1444 ${ }^{51}$, s. 189-192.

32. De rege Ladislao [Aeneas Silvius Dionisio Szécsy, archepiscopo Strigonensi, sanctae Romanae ecclesiae presbytero cardinali] - Ex Gretz ${ }^{52}$, s. $192-197$.

33. Reverende in Christo pater et domine mi praecipue - Ex Vienna $15 \mathrm{kalendas}$ ianuarii $1446^{53}$, s. 197-199.

Najprawdopodobniej jest to list Eneasza do Jana Carvaiala, wtedy jeszcze biskupa, purpure kardynalskq otrzymal on bowiem dopiero w grudniu 1446. Mówi o tym, że sq jeszcze ci, którzy wierza w powrót polskiego króla Wladyslawa, niczym $w$ drugiego Herkulesa wychodzqcego z podziemi. Twierdzi też, ze sq tacy, którzy chcieliby odebrać królestwo węierskie prawowitemu królowi, o czym $z$ calq pewnościq wie Kuria Rzymska. Podobnie ironicznego sformulowania o Wladyslawie Warneńczyku użyl Eneasz także w liście do Jana Campisiusa z 4 stycznia ${ }^{s t}$, ale ten list z pewnościq nie jest do Campisiusa, o czym świadczy fakt, ze Eneasz mówi tutaj o nim w trzeciej osobie.

34. Epistula Iohanni [Carvaial], sancti Angeli cardinali Aeneas Silvius - Ex Tergesto die 25 iulii $1448^{55}$, s. 199-200.

${ }^{48}$ Wolkan III, nr 1, s. 3-4.

4) Jest to prawdopodobnie odpowiedź na list Eneasza z 13 września 1445 roku (Wolkan I nr 185 , s. 538). Tego listu Campisiusa nic ma w edy cji Wolkana.

5" Nie ma u Wolkana.

${ }^{51}$ Wyd. bazyl. ep. 111, Voigt, nr 110, Wolkan I, nr 144, s. 326-331.

${ }^{2}$ Wyd. bazyl. ep. 13, Voigt, nr 45, Wolkan 1, nr 76, s. 182-187. Wolkan datuje na 16 . kalendis octobris 1443.

${ }^{53}$ Nie ma w edyeji Wolkana.

"st Por. Wolkan III, nr 2, s. 4-6.

${ }^{55}$ Nie ma w edycji Wolkana. 
35. „vincula verberea” [wyd. baz., s. 679c] - „oppida bello" [wyd. baz. s. 685c], s. 201-211. [Oratio Aeneae Silvii de Constantinopolitana clade et bello contra Turcos congregando] in conventu Francofordiensi mensis octobris 1454.

Brak poczqtku i konca mowy ${ }^{56}$.

36. Beatissime patre et domine, vir clementissime - Post datum in oppido Francofordiensi [mensis octobris] 1454 [Aeneas ad papam Nicolaum V ] ${ }^{57}$, s. 212-213.

37. „opida bello nec tarda senectus vestra viros debilitet amittatque vigores" s. $215-227$.

Dalszy ciag (do końca) mowy Eneasza wymienionej w pozycji 35.

38. Quamvis omnibus, qui adestis Reverendissimi Patres illustrissimi et exelentissimi principes magnifici et praestabiles domini - Et omnes qui spem habent in hac dieta, quem per prestolentum fructum accipiunt [Oratio Vilhelmi, episcopi Thulensis, legati Philipi ducis Burgundiae in conventu Francofordiensi mensis octobris 1454], s. 229-241 ${ }^{58}$. Mowa zachowana w calości.

39. Auctore benedicto et glorioso domino nostro Iesu Christo, qui ecclesiae catholicae suae, matri nostrae in onnibus necesssitatibus adest. In hoc conventu Francofordiensi ex visione divi caesaris Friderici Romanorum imperatoris Augusti domini nostri invictissimi in legati apostolici praesentia ad infra scripta deventum est - mihi liquet, s. 242-24759.

Ustalenia konwentu frankfurckiego.

40. In celiberrimo conventu habito apud Tranchfordiam - consumata est dieta cum felici exitu et optima concordia, s. 247-251.

Lista obecnych na sejmie frankfurckim w' 1454 poslów i ambasadorów.

41. Consilium recupandi pecuniae in causa Turcorum - Itemque legatus sanctissimi domini nostri qui ad dietam in Nova Civitate tenenda veniat litteras et bullas apostolicas oportunas et etiam indulgentis ut permittitur secum afferat et adducat, s. 252-254.

42. Oratio domini episcopi varadiensis Pulsutis muerore publico - Oratio habita in Nova civitate coram imperatore Fridderico Tertio pro facto Turcorum per Iohannem, episcopum Varadiensem [János Vitéz, biskup Waradynu, znany humanista wçgierski] cancellarium tunc unum ex oratoribus Regis Hungariae 23 die mensis Martii anno domini 1455, s. 255 -280 .

Sejm w Neustadt.

${ }^{56}$ Wyd. bazyl. ep. 130, s. 678-689.

${ }^{57}$ Nieznany Voigtowi, u Wolkana nie zdołałam sprawdzić z powodu niemoźności sprowadzenia do Lublina IV tomu.

${ }^{58}$ Nie ma w edycji Wolkana.

5\%) Nie ma w edycji Wolkana. 
43. Ad serenissimum dominum Fridericum imperatorem lohannis de Castilonio, episcopi Papiensis et comitis apostolici legati exhortatio ad defensionem fidei in Turcos - cetera meae legationis suo loco ac tempore pro tuae voluntatis arbitrio liber semper absolvam 1454 anno, s. 283-294.

Konwent w Ratyzbonie 1454.

44. Ad serenissimum Dominum Ladislaum Hungariae ac Bohemiae Regem, lohannis de Castilonio, episcopi Papiensis et comitis legati apostolici exhortatio in Turcos - tu felicem faciat amen s. 295-304.

Konwent w Ratyzbonie maj 1454.

45. Ad reverendissimos prelatos et illustres barones Regni Hungariae Iohannis de Castilonio, episcopi Papiensis et comitis apostolici legati exhortatio in Turchos - et optatum s. 305-317.

Konwent w Ratyzbonie maj 1454.

46. Iohannis de Castilonio, episcopi Papiensis et comitis apostolici Papae legati addicta Ratisponensis exhortatio in Turcos - Iesus Christus, qui nos omnes sua pietate felices faciat amen, s. 318-333.

Konwent w Ratyzbonie maj 1454.

47. Iohannis de Castilonio, episcopi Papiensis et comitis s. d. n. papae legati addictam Francofordensi exhortatio in Turchos - est vera salus lesus Christus Deus et Dominus noster amen, s. 335-346. Konwent frankfurcki, październik 1454.

48. Aderat nuper caesarea maiestas multorum baronum ac nobilium — vestro gravi et optimo indicio nihilominus salvo, s. 347-359.

Traktat o problemach literackich, ok. $1454^{60}$.

49. Ea sublevatio - vale, s. 359-360.

List Eneasza Sylwiusza do Gunifortusa Barizzy, którego pelny naglowek w edycji Wolkana brzmi: Aeneas Silvius poeld, salutem plurimam dicit domino Guniforto, utriusque intris doctori ducalique secretario, amico precipuo. Datowany tam: Ex Feltkirchen nonis decembribus 1442 roku. W kodeksie Szembeka niepelny odpis listu (brak jego drugiej polowy) bez podania nadawcy, adresata oraz datacji. $U$ Wolkana datowany jest: Ex Feltkirchen nonis decembribus $1442^{61}$.

50. Debes dare veniam occupationibus meis - ad te ducam [Venceslaus Bohemiae Ioanni canonico Vratislaviensi, ex Vienna die XV mai $1443^{62}$ ], s. 360 .

51. Litteris tuis, quas Plumbini accepi, utor iucundissime - participabamque cum patre amavitudinem, s. 361

Jest to list Eneasza Sylwiusza do Georgiusa Andrenciusa ze Siemy. W kodeksie nie podano nadawcy, adresala ani datacji, brak również końca listu, odpis

${ }^{60}$ Wyd bazyl. cp. 104.

${ }^{6}$ Wyd. norym. 30, bazyl. ep. 30; Voigt, mr 10; Wolkan I, nr 40, s. 177-119.

${ }^{62}$ Ten sam list adresowany i datowany w ten sposób znajduje się w kodeksie nr 401 Codices Urbinates Latini Bibliothecae Vaticanae, rec. Cosimus Stornajdo, t. 1, Codices 1-500, Romae, Typis Vaticanis 1902, s. 395. 
kończy się slowami: „participabam cum patre amaritudinem”. U Wolkana podano: Ex Mediolano, orientacyjnie Wolkan datuje ten list na koniec marca ${ }^{63}$ 1432 .

52. Nescio quid causae sit, loannes mi dilectissime - scribendo saepius efficies. Valve, s. 361-362

List Eneasza do Jana Aurispy, datowany w edycji Wolkana orientacyjnic - Siena koniec 1431 roku ${ }^{64}$. W kodeksie nie podano adresata, nadawcy ani datacji.

53. Aeneas ad dominum Petrum de Noxeto. Mirabar dudum, quid rei esset, quod ad me nihil scriberes - una epistola compensare silentium. Valcte, s. 362-363

$W$ kodeksie brak datacji, $u$ Wolkana: Ex Nova civitate, orientacyjnie datowany na poczqtek sierpnia 1443 roku ${ }^{05}$.

54. Adam ad d. Aeneam. Amantisssime frater. Modico nunc superiori tempor - vale felix, optime et antique socie, s. 363

List Adama de Molin, Anglika, do Eneasza Sylwiusza. W kodeksie brak datacji, Wolkan orientacyjnie datuje: Londyn poczatek sierpnia $1443^{66}$.

55. D. E. ad Johannem Campisium. Aliorum litteras que ad me scribuntur- Nam mei aliquando amicus fuit et nunc est. Vale, s. 364-367 List Eneasza Sylwiusza do Jana Campisiusa, w kodeksie bez datacji, u Wolkana: Ex sancto Vito in carinthia, die 13 ianuarii anno $1444^{67}$.

56. Responsio data legatis Hungarorum nomine Imperatoris per dominum Aeneam, episcopum Senensem, die XXIII Martii 1455. Si mihi Reverendissimi patres Nobiles - Ac tantum desperanda victoria satis fuerit esse locutum. Et sic est finis huius responsionis, s. 379-396.

57. Doctissimo et reverendissimo patri domino IohanniVaradiensi, regni incliti Hungariae cancellario Aeneas Silvius episcopus Senensis et imperialis consiliarus - Ratisbone habita prosequatur, s. 403-510

[Oratio habita in conventu Ratisponensi mensis mai 1454] ${ }^{68}$.

58. De coniugio - Haec oratio edita per reverendissimum patrem dominum Aeneam episcopum Senensem, imperialis dignitatis consiliarum, de sponsalibus perorata in castro minori Neapolitano in pracsentiarum illustissimi principis et domini Alfonsi regis Portugaliae et caetera potentissimi nec non reverendissimis partibus domini cardinalis Mormensis, vulgaliter nuncupati Archiepiscopi Neapolitani, episcopi Ocselensis et aliorum episcoporum venerabilium undecima mensis decembris 1450 in fine iubilei. Et tunc

${ }^{63}$ Wyd. norym. 33, wyd. bazyl. cp. 33; Voigt, nr 2; Wolkan I, nr 7, s. 11-12.

${ }^{64}$ Wyd. norym. 34, bazyl. ep, 34, Voigt, nr 1; Wolkan I, nr 2, s. 2-3.

${ }^{65}$ Wyd. norym. 36, bazyl. ep. 36, Voigt, nr 32; Wolkan I, nr 70, s. 172-173.

65 Wyd. norym. 199, bazyl. ep. 186, Voigt nr 23; Wolkan I. m 69, s. 171-172.

${ }^{67}$ Wyd. norym. 44, bazyl. ep. 44, Voigl, nr 91; Wolkan I, nr 117, s. 278-283.

6" P'ii II orationes, ed. G. Mansi, I ucae 1759; Wolkan IV, nr 291, s. 492-563-drukuje na podstawie edycji Mansicgo i rękopiśmiennych kodeksów watykańskich., gdzie indziej nie publikowano. 
XIX die dictae mens pressura fuit enormis et multitudo christianorum utriusque sexus in ponte sancti Angeli Romae compressi sunt usque ad mortem numero circiter quadringenti ${ }^{69}$, s. 511-526

Mowa wygloszona z okazji zaręczyn Fryderyka III z Eleonorq portugalska w Neapolu 11 grudnia 1450 roku.

59. Fateor beatissime maxime pontifex - arbitris referemus, s. 531-54170. Mowa Eneasza Sylwiusza przed papieżem Mikolajem $V w$ sprawie koronacji Fryderyka III na cesarza, wygloszona w Rzymie na poczatku 1451.

60. Aeneas, episcopus Tergestinus, domino Michaeli Phulendorf, regio secretario et amico fideli - Ex Balneis 14 kalendas Martii 1449, s. 543 $-544^{71}$

61. Doctissimo viro, domino Iohannni Campisio, philosopho, Aeneas, episcopus Tergestinus - Ex Nova civitate 10 decembris 1449, s. $545^{72}$.

62. Claro et praestanti iurisutriusque consulto, domino Nicolao de Arzimboldis, amico singulari, Aeneas, episcopus Tergestinus [Ex Nova civitate 6.] kal. decembris 1449 , s. 546-54773.

63. Viro singulari atque doctissimo domino Francisco Philepho, saturarum scriptore Aeneas episcopus Tergestinus - Ex nova civitate 6. kalendis decembris 1449 , s. 547-54874.

64. Bartholomeo Regna, [civi] Mediolanensis, viro docto et nobili, Aeneas episcopus Tergestinus - Ex Nova civitate 6. kalendis decembris 1449, s. $548-549^{75}$.

65. Aeneas, episcopus Tergestinus, domino Caspari Slick, imperiali cancelario - Ex Pisino, Histrie oppido idibus septembris 1448, s. 551-558 ${ }^{76}$.

66. Aeneas, episcopus Tergestinus, viro docto domino Iohanni Hinderbach, secretario regio et amico singulari - Ex Tergesto die 26 mensis iulii 1448, s. $558-559^{77}$.

67. Aeneas episcopus Tergestinus viro claro et optimo Iohanni Tusthoni insignis civitatis Pragensis secretario - Ex Vienna 2 idibus novembris 1446 , s. $559-560^{78}$.

68. Patri sancto, Iohanni, abbati Monasterii sanctae crucis in Austria, theologo

"Nie ma w edycji Wolkana.

${ }^{70}$ Nie ma w edycji Wolkana.

${ }^{71}$ Nie ma w edycji Wolkana.

${ }^{72}$ Wolkan JII, nr 36, s. 97-98.

${ }^{73}$ Wolkan III, nr 33, s. 94-95.

${ }^{74}$ Wolkan III, nr 32, s. 93-94.

${ }^{75}$ Wolkan III, nr 34, s. 95-96.

${ }^{76}$ Wyd. bazyl. ep. 110; Voigt nr 180; Wolkan III, nr 22, s. 67-71.

${ }^{77}$ Nic ma w edycji Wolkana.

${ }^{78}$ Wolkan IIl, nr 16, s. 51-52. U Wolkana jest tylko ex Vienna, bez daty, Wolkan datuje orientacyjnie na połowę czerwea 1447. 
perspicati, Aeneas episcopus Tergestinus - Ex Balaeis Vienensibus mensis 15 kalendis februarii 1449 , s. $560-562^{79}$.

69. Sancto patri, domino Silvesto pontifici Chiemensi, Aeneas episcopus Tergestinus - Ex Balneis Australibus 15 kalendis februarii 1449, s. 562$-564^{80}$.

70. Veneberabili et docto patri domino Urlico Sonnenberg, regio consiliario, Aeneas episcopus Tergestinus - Ex Nova civitate die 18 februarii 1449, s. $565-566^{81}$.

71. Ioannes Huniad, Transilvaniae dux gloriosi regni Hungariae gubernatori Omarach magno Turcorum imperatori - mundi brevi futurorum putamus. Datum, s. 567-581 ${ }^{82}$.

72. Revendissimo in Christo patri domino Sbigneo sacrosanctae romanae ecclesiae Romae sedis in sanctae Priscae presbytero cardinali dignissimo et venerando presuli Cracoviensi Aeneas episcopus Senensis - Ex Vienna die 28 mai 1451 , s. 582-58583.

73. Reverendo in Christo patri fratri, Iohanni de Capistrano ordinis minoris professori ac vicario generali Aeneas episcopus Senensis - Ex Vienna die V Iunii $1451^{84}$, s. 586-588.

Rękopis z listami i mowami Eneasza Sylwiusza Piccolominiego pochodzacy z biblioteki hr. Jerzego Szembeka jest z pewnością ważnym źródłem historycznym. Wprawdzie w XV wieku kodeksów z listami Eneasza Sylwiusza krążyło w Europie Zachodniej mnóstwo, o czym wspomina nawet sam Eneasz, trudno byłoby jednakże znaleźć teraz dwa takie same kodeksy. Nic dziwnego, Eneasz pozostawił łącznie około tysiąca listów z okresu świeckiego, biskupiego i kardynalskiego, dlatego, choć wiele $z$ nich powtarza się $w$ różnych kodeksach,

${ }^{79}$ Wolkan III, nr 24, s. 78-79.

"1) Wolkan III, nr 29, s. 85-87 - podaje tylko rok, bez dokładnej daty i micjsca.

${ }^{81}$ Nie ma w edycji Wolkana.

82 Drukowany częściowo w Codex epistolaris, t. 3, nr 18, s. 24-25. Wydawca, A. Lewicki, nie miał prawdopodobnie dostępu do rękopisu i publikował list tylko na podstawie notatek po zmarłym profesorze Szujskim i z tego względu wydał go fragmentarycznie, pod błędnym tytułem i z pewnymi błc̨dami. Jak słusznje bowiem zauważył Ignacy Zarębski w swcj pracy Stosınki Eneasza Sylwiusza - Polskq i Polakami (Kraków 1939, s. 13, przypis 3) tekst opublikowany przez Lewickiego jako list Hunyadego do sułtana Murada, w rzeczywistości zostal napisany przez Encasza, który posługując się imieniem wielkiego wroga Turków, Hunyadego, odpowiada na pewien paszkiwil nieznanego autora chwalący Turków, a atakujący Węgrów. O tym, że list pisał Encasz, potwierdził on sam w liścic do Urlyka Sonnenberga, który w naszym kodeksie się znajduje na s. 565-566, ratomiast Wolkanowi, jak i innyın wydawcom, jest nicznany. Zob. Z a r ę b s k i, Stosunki, s. 13-15.

${ }^{83}$ Drukowany w Codex epistolaris, t. 1, cz. 2 wydanej przez J. Szujskicgo s. 118-119, ale z datą 24 maja 1451, ponieważ publikowano go nie z kodeksu Szembeka, lecz z kodeksu Epistolarum et epitaphiorum liber nr 48 (obecnie sygnatura kodeksu nr 42) ex Bibliotheca Universitatis lagiellonicae, s. 80. Na podstawie Codex epistolaris drukuje go także Wolkan IV, nr 4, s. 8-10.

${ }^{84}$ Wolkan IV nr 9, s. 19-20. Ten sam list do Jana Kapistrana występuje w składce 4 kodeksu Szembeka, sporządzony przez innego kopistę. Zob. poz. 16, s. 59-60. 
prawie w każdym można też znaleźć i takie mniej spotykane, czy nawet zupehnie nieznane. Nasz kodeks zawartością różni się zarówno od kodeksów „Urbinates” $i$,Reginae Sueciae" znajdujących się w Bibliotece Watykańskiej, jak i od kodeksów z Biblioteki Wiedeńskiej. W Polsce znane są, oprócz kodeksu Szembeka, trzy kodeksy zawierające większą liczbę listów Eneasza Sylwiusza - kodeks nr 7804 III z Biblioteki Jagiellonskiej, kodeks nr 601 z Biblioteki Ossolineum we Wrocławiu, a także kodeks nr 229 z Biblioteki Kapituły Krakowskiej na Wawelu. Pojedyncze listy występują w kodeksie nr 42 i 173 Biblioteki Jagiellońskiej, późniejsze zaś, już z czasów pontyfikatu, znaleźć można w kilku innych kodeksach, m. in. w kodeksie ur 423 Biblioteki Jagiellońskiej. Kodeks Szembeka jest o tyle specyficzny, że dotyczy w calości Eneasza Sylwiusza, mowy innych osób pojawiają tylko w kontekście jego działalności i występują jako jedna ze stron w konkretnych sprawach, gdzie i Eneasz aktywnie uczestniczył np. na sejmie w Ratyzbonie, Frankfurcie i Neustadt. Material jest obszerny, liczy 588 stron, podczas gdy inne polskie kodeksy posiadają dużo mniej twórczości Eneasza i zawierają rzeczy różne. Najwięcej jest jej chyba w kodeksie nr 7804 III Biblioteki Jagiellońskiej. Korespondencja Eneasza z lat 1442-1446 (ponadto jeden list $z$ roku 1450) mieści siç tam na 96 kartach in folio pisana $w$ dwóch kolumnach (k. 49-146v) ${ }^{85}$, odpisy powstawały w latach $1475-1489^{86}$. Kodeks nie zawiera jednak listów nieznanych Wolkanowi. Dużągrupę listów Eneasza mamy też w kodeksie nr 601 Biblioteki Ossolineum we Wrocławiu. Tam mieszczą się one lącznie na 108 kartach in 4to (k. 121-219 oraz 358v-365) ${ }^{87}$. Kodeksu tego nie widziałam, nie umiem więc stwierdzić dokładnie, jakie są to listy i czy wszystkie były już publikowane, $\mathrm{z}$ pewnością jest tam kilka $\mathrm{z}$ lat 1444-1445, a pośród nich nowela o Eurialu i Lukrecji. Natomiast w kodeksie kapituły krakowskiej, datowanym przez kopistę na rok 1473, korespondencja Eneasza zajmuje 82 karty in 4to ${ }^{88}$. Znajdują się tu, jak podaje Józef Szujski, listy przeważnie z roku 1450, z których część nie była znana G. Voigtowi ${ }^{89}$, ponieważ jednak do tego kodeksu też nie miałam dostępu, nie znam dokładnie jego zawartości i nie moge stwierdzić, czy wszystkie znajduja się w edycji Wolkana. Józef Szujski przypuszczał, że kodeks kapitulny mógł być odpisem slynnego kodeksu przesłanego przez Eneasza Sylwiusza kardynałowi Zbigniewowi Oleśnickiemu w 1451 roku ${ }^{90}$. Z pewnością jednak nie można się z tym stwierdzeniem zgodzić, ponieważ, co potwierdzają cytowane poniżej lis-

${ }^{85}$ Zob. Inwentarz rękopisów Biblioteki Jagiellońskiej, cz. 3, opr. A. Jałbrzykowska, Kraków 1967, s. 5-13.

${ }^{86}$ Ibidem s.11-13.

${ }^{87}$ Zob. Katalog rẹkopisów Biblioteki Zakladu Narodowego in. Ossoliniskich, wyd. W. Kẹtrzyński, t. 3, Lwów 1898, s. 76-80.

${ }^{8 R}$ Zob. Katalog rekopisów kapitulnych katedry krakowskiej, cz. 1, Kodexa rękopiśmienne nr 1-228, oprac. I. Polkowski, Kraków 1884, poz. kat. 221 nr 229, s. 157-158

${ }^{89} \mathrm{Zob}$. Codex epistolaris, s. LXI-LXII.

"Ibidem . 
ty Eneasza, kodeks ten zawierał korespondencje z okresu przed osiągnięciem godności biskupiej, a w kodeksie kapitulnym są w większości listy z 1450 roku, zatem dużo późniejsze.

W tym miejscu pozwolę sobie przypomnieć historic̨ darowanego Oleśnickemu kodeksu, która jest dziś o tyle interesująca i warta uwzględnienia, ponieważ niektóre zachowane w Polsce rękopisy moga częściowo, a nawet w całości, być późniejszymi jego odpisami. Pierwsze wzmianki o nim podaje Eneasz w liście do Oleśnickiego z dnia 23 lutego 1450 roku, w którym skromnie wzbrania się pokazać swoje pisma tak uczonemu człowiekowi, jakim jest polski kardynał, nie chcąc jednak odmówić prośbie dostojnego przyjaciela o przysłanie listów, oświadcza, że zlecił skrybie ich przepisanie i przekaże je powracającemu do Polski Janowi Długoszowi ${ }^{91}$. W kolejnym liście Eneasza do Oleśnickiego z dnia 16 lipca 1450 roku padło już wyraźne stwierdzenie, że listy zostały podzielone na dwa tomy: jeden zawierający korespondencję z czasów, gdy był jeszcze osobą świecką (litterae saeculares), w drugim natomiast były listy pisane po otrzymaniu. godności biskupiej Triestu i Sieny (litterae pontificales). Tom saecularium litterarum dał do przepisania, po czym osobiście poprawił, nie mógł go jednak przesłać w darze kardynałowi z powodu braku odpowiedniego wysłannika: ,epistolas meas, quibus amicos alloquor, tibi ut ederem sepius flagitasti. volui tuo desiderio morem gerere, commisi librario meo, non ut optarem terso opus ut transcriberet. ego interim in Histriam sum profectus. duo sunt epistolarum volumina, alterum saecularium, alterum pontificalium. seculares sunt litterae, quas ante pontificatum mihi delatum conscripsi; quicquid postea scriptum est, ex pontificio nomen habet. Cum redii ex Tergesto, comperi alterum volumen absolutum secularium litterarum. Hoc correxi dignationique tuae mox transmitterem, si bajules esset fidus. Sed non novi homines, qui ad te proficiscantur maloque serius et utiliter mittere quam celeriter in vanum. Tu ergo, si quem scis huc venturum, qui rediturus ad te sit, probate fidei, scribito mihi et cuicunque miseris librum consignabo. Habet autem liber sexternos duo deviginti; nugas quam plures continet, quas dum lego mei me pudet, nec ullo pacto tantas ineptias in lucem darem, nisi tua me cogeret auctoritas, cui negare nihil possum. Aliud quod modo scribam nihil habeo. pontificalium litteratum liber, cuius faciam copiam, minus enim stultitiae et plus, ut mili videtur, nervorum habet plusque salis, nisi senescentes desipimus et opera nostra plus equo diligimus" ".92. Kodeks litterarum pontificalium, chociaż bardziej dojrzały w treści i z tej racji bardziej odpowiedni dla dostojnego przyjaciela, nie był wtedy jeszcze gotowy do wysłania, Eneasz dopiero zlecił jego skopiowanie. Kodeks zaś litterarum saecularium, obejmujący osiemnaście seksternów, dotarł do Oleśnickiego w połowie 1451 roku wraz z kolejnym listem Eneasza datowanym na 24 maja 1451. Eneasz pisze w nim: „Epistolae, ut ante dixi, me abeunte hic transscriptae manserunt usque in hanc diem neque petitae neque vocatae, nunc ad te venient re-

${ }^{91}$ Codex epistolaris, s. 335-336, Wolkan III nr 41. s. 158-160.

"22 Wolkan III, nr 42 s. 160-162. 
quisitae, si fides est nuntio, nihil adversi tulerint in via, utinam dignae sint visione tua, tuis alloquiis et tuas incolere bibliotecas. Ego illas ad te mitto non honorandas sed potius tuo acri et gravi iudicio corrigendas expoliendasque. Nihil ibi tuis moribus tuaque dignitate dignum reperies, saeculares non pontificales epistolae sunt, lusimus iuvenes nondum sacramentis ecclesiasticis iniciati, sapiunt omnia saecularem, quae ante pontificatum scripsimus, et fortasse nimis mundiales fuimus. Nunc tum aetas, tum dignitas, aliam vitam, alios mores, alia scripta ex me postulant. Ideo, quae post adeptum episcopatrum scripsi, in aliud volumen redigi curo, cuius etiam aliquando poteris fieri particeps, si te meas ineptias legere iuvat" ${ }^{\prime 3}$

Zapewne zatem przygotowywana kopia litterarum pontificalium, o której mówił w liście z lipca 1450, nie została wtedy przesłana Oleśnickiemu. W liście z maja 145 I roku, cytowanym wyżej, Eneasz mówił tylko, że może mu ją przesłać, jeśli jego listy zainteresują kardynała. Ponieważ jednak Oleśnicki nie odpowiadał na ten list Eneasza aż do września 1453 roku, do tego czasu Eneasz nie wiedział, z jakim kodeks spotkał się przyjęciem i czy Oleśnicki zechce przeczytać drugi tom listów. Ale w odpowiedzi Oleśnickiego nie było nawet cienia krytyki, z zachwytem przyjął twórczość Eneasza i nie zraziła go nawet lekka treść listów. Docenił talent pisarski Sieneńczyka, traktując frywolne opowiastki (zapewne chodzi tu o nowelę o Eurialu i Lukrecji) jako fikcję literacką dozwoloną każdemu poecie. Tak entuzjastyczne przyjęcie było dla Eneasza miłym zaskoczeniem. Świadczy o tym list z 27 października 1453 roku, będący odpowiedzią na wrześniowy list Zbigniewa. Zaznaczył w nim, że pochlebna opinia polskiego kardynała jest dla niego wielkim zaszczytem i stwierdził, że jego słowa będzie odtąd umieszczał na poczatku swoich pism, aby stanowiły przeciwwage dla słów ewentualnej krytyki: „Noluisti deinde meis epistolis, quae iam currere per Germaniam coeperant, opinionem demere. Ago gratias humanitati tuae, quae de suo iudicio, quam de mea fama maluit haesitari, nom ini meo vel cum tuo detrimento consulere voluisti. Videor videre commmendatione tua ingentem meis epistolis favorem accedere. Quis enim post hac illas carpere audeat, quas noverit tuo testimonjo comprobatas. Ego quidem, quod a te modo scriptum est, in capite voluminis collocabo, ne quis mea prius legat scripta, quam tua noverit auctoritate legenda, et si enim Apolinis illud responsum memoriae teneo, quo se quemquam noscere iubet, gaudeo tamen nomen meum quocunque pacto illustrari" ".4. Znamienne, że rękopis Szembeka, jako jedyny ze znanych mi kodeksów polskich, zawiera list Oleśnickiego z pochwałami Eneaszowego kodeksu na początku, tak właśnie, jak to zapowiedział Eneasz. Niewykluczone więc, że to właśnie składki z pismem włoskim zamieszczone w kodeksie Szembeka mogą bezpośrednio pochodzić od Eneasza i być owymi litterae pontificales, które dał on do przepisania specjalnie dla Zbigniewa. Ostatnie daty w kodeksie kończą się na marcu 1455 roku, a więc jeszcze przed śmiercią Oleśnickiego (zm. 1 kwietnia 1455 roku). Trudno stwierdzić, czy drugi kodeks

\footnotetext{
${ }^{93}$ Codex epistolaris, s. 118-119. Wolkan IV, nr 4, s. 8-9.

${ }^{94}$ Codex epistolaris, s 323-324.
} 
rzeczywiście przesłano Oleśnickiemu i czy dotarł on do niego jeszcze za jego życia. Nie wiadomo, co dokładnie zawierał, musiałyby to być jednak listy z czasów gdy Eneasz był biskupem Triestu i Sieny. Porównując zaś kodeks Szembeka z innymi polskimi kodeksami zawierającymi korespondencje Eneasza, okazuje się, że zebrano w nim najwięcej listów z tego właśnie okresu. W każdym razie kodeks Szembeka, jeśli jest tym drugim, dla niego przygotowanym, jest nim z pewnością tylko w części. Jak wyżej powiedziano, jest tworem niejednolitym, zawiera składki przepisywane w różnym czasie, przez różnych kopistów. Mógł być później uzupełniany, poprawiany i oprawiony w Polsce, ale mógł też w całości być tylko odpisem tamtego. Jakie by jednak nie było rzeczywiste pochodzenie kodeksu, jest on źródłem bardzo cennym, układ listów jest zupełnie inny niż w wydaniu norymberskim i bazylejskim, sq̨ też listy nieznane Voigtowi, a nawet Wolkanowi. Niektóre Wolkan pominął nie natrafiwszy na nie w dostępnych sobie wydaniach i rękopiśmiennych kodeksach, inne zaś wydać prawdopodobnie nie zdążył, ponieważ tom czwarty jego edycji kończy się na czerwcu 1454 roku, w kodeksie Szembeka ostatnią datą jest, jak wspomniano wyżej, 23 marca 1455 roku. Są też rzeczy, które u Wolkana nie występują np. poselstwo Eneasza z prośbą o rękę Eleonory portugalskiej dla Fryderyka III, czy mowa Eneasza na zarçczynach tej młodej pary w Neapolu 1451 roku, a także mowa przed papieżem Mikołajem V w sprawie koronacji Fryderyka na cesarza, ponadto list Eneasza Sylwiusza do Urlyka Sonnenberga i kilka innych. Należy równjeż dodać, że listy, które zamieszczone są w znanych wydaniach up. bazylejskim, czy Wolkana, w kodeksie Szembeka maja niekiedy nieco inne warianty słowne, a niekiedy nawet inną datację. Ciekawą sprawą byłoby tez zbadanie tych wersji, czy były one mało istotne, czy znaczne, czy mogły wynikać z pomyłki kopistów czy też były świadomie zamierzone, a jeśli tak, jak one się mają do innych wariantów tych samych tekstów, czy powodem zmian były czasami względy dyplomatyczne lub samowola kopisty mająca na względzie np. polskiego czytelnika. Kodeks dotyczy w dużej części czasów, kiedy zagrożenie ze strony Turcji było coraz większe. Dlatego nie ma tu bardzo dużo zjadliwych ataków na polskiego króla Władysława poległego pod Warna, choć niektóre listy jeszcze go krytykują. W kontekście jednak apologii Warneńczyka przedstawionej przez Zbigniewa Oleśnickiego oraz na tle ówczesnych wydarzeń - upadku Konstantynopola i mało skutecznych prób przygotowania krucjaty przeciwko Turkom - poglądy Eneasza uległy już pewnemu przeobrażeniu i nie były tak wrogie Polsce, jak to miało miejsce na początku lat czterdziestych, gdy trwała nieustająca walka o koronę węgierską. Polskim akcentem w kodeksie Szembeka jest wzmianka o Lutku z Brzezia, późniejszyın rywalu Eneasza do biskupstwa warmińskiego, w relacji z sejmu w Ratyzbonie w 1454, przekazanej przez Eneasza w liście do Jánosa Vitéza ${ }^{95}$. Lutek uczestniczył tam aktywnie jako poseł Kazimierza Jagiellończyka. Natomiast na konwencie frankfurckim poselstwa polskiego nie było, Polska zajęta była wojną z Zakonem krzyżackim. Jej udział

's5 Kodeks Szembcka, s. 448. 
w ewentualnej krucjacie Eneasz skwitował słowami:. „Rex Poloniae cum religiosis beatae Mariae Theutonicorum bello implicatur, nisi pacificetur, potius damno erit, quam auxilio"96. Do polskich akcentów można zaliczyć, oprócz listu Zbigniewa do Eneasza $z$ września 1453 i Eneasza do Zbigniewa $z$ maja 1451, jeszcze list Eneasza do Jana Carvaiala z końca 1445 roku, dotąd nieopublikowany, a także list pisany w imieniu Hunyadego do sultana tureckiego, Omara, publikowany w części przez A. Lewickiego. Wydaje sic̨, że kodeks posiadając kilka tekstów niepublikowanych nigdzie indziej może wnieść kilka nowych, istotnych szczegółów nie tylko dla zainteresowanych działalnością Eneasza Sylwiusza Piccolominiego, ale także w ogóle, do historii piętnastowiecznej Europy. Niewątpliwie będzie więc pożytecznym źródłem dla polskiej mediewistyki.

\section{BIBLIOGRAFIA}

\section{Kodelksy rękopiśmienne z XV wieku zawierające listy Eneasza Sylwiusza Piccolominiego}

Biblioteka Uniwersytecka KUL, sygn. 2625, Kodeks z Biblioteki hrabiego Jerzego Szembeka z Poręby.

Biblioteka Jagiellońska, Kodeks nr 42.

Biblioteka Jagiellońska, Kodeks nr 173.

Biblioteka Jagiellońska, Kodeks nr 7804 III.

\section{Publikowane katalogi rękopisów}

Catalogus codicum manuscriptorum medii aevi latinorum qui in Bibliotheca Jagiellonica Cracoviae asservantur, oprac. Z. Włodek, J. Zathley, M. Zwiercan, vol. 1-7, Wratislaviae - Varsaviae - Cracoviae - Gedani, 1980-2000.

Codices Urbinates Latini Bibliothecae Vaticanae, rec. Cosimus Stornajdo, t. 1, cod. 1-500, Romae Typis Vaticanis 1902.

Inwentarz rękopisów Biblioteki Jagiellońskiej, cz. 3, oprac. Anna Jałbrzykowska, Kraków 1967.

Katalog rękopisów Biblioteki Zakladu Narodowego im. Ossolińskich, wyd. W. Kętrzyński, t. 3, Lwów 1898.

Katalog rekopisów kapitulnych katedry krakowskiej, cz. 1, Kodexa rękopiśmienne $n$ 1-228, oprac. Ignacy Polkowski, Kraków 1884.

Tabulae codicum manu scriptorum in Bibliotheca Palatina Vindobonensis asservatorum, ed. Akademia Caesarea Vindobonensis, vol. 2, Vindobonae 1868. 


\section{Wydania korespondencji Eneasza Sylwiusza Piccolominiego}

Aeneae Sylvii Piccolominei Senensis, qui post adeptum pontificatum pius eius nominis secundus apellatus est, opera quae extant omnia, Basileae, ex officina Henri Cpetrina cum gratia et privilegio Caes. Maiest. 1571. Aeneae Sylvii Pii Pontificis epistolarum liber, s. 500-962.

Die Briefe des Aeneas Sylvius vor seiner Erhebung auf den päpstlichen Stuhl, chronologisch geordnet und durch Einfügung von bisher ungedructen vermehrt, als Vorarbeit zu einer künftigen Ausgabe dieser Briefe von Georg Voigt, w: Archiv für Kunde östereichischer Geschichts-Quellen, herausgegeben von der zur Pflege vaterlündisicher Geschichte aufgestellten Kommission der keiserlichen Akademie der Wissenschaften, Band 16, Wien 1856, s. 321-424.

Der Briefwechsel des Eneas Silvius Piccolomini, herausgegeben von Rudolf Wolkan, Abteilung I: Briefe aus der Lciienzeit (1431-1445), Band 1: Privatbriefe, Wien 1909, w: Fontes rerum Austriacarum - Österreichische Geschichts-Quellen, herausgegeben von der historischen Kommission kaiserlichen Akademie der Wissenschaften in Wien, Abteilung 2: Diplomataria et Acta, Band 61, Wien 1909 [cytowane jako Wolkan I].

Der Briefwechsel des Eneas Silvius Piccolomini, herausgegeben von Rudolf Wolkan, Abteilung 1: Briefe aus der Laienzeit (1431 - 1445), Band 2: Amtiche Briefe, Wien 1909, w: Fontes rerum Austriacarum - Österreichische Geschichts-Quellen, herausgegeben von der historischen Kommission kaiserlichen Akademie der Wissenschaften in Wien, Abteilung 2: Diplomataria et Acta, Band 62, Wien 1909 [cytowane jako Wolkan II].

Der Briefwechsel des Eneas Silvius Piccolomini, herausgegeben von Rudolf Wolkan, Abteilung 2: Briefe als Priester und als Bischof von Triest (1447-1450), Wien 1912, w: Fontes rerum Austriacarum - Österreichische Geschichts-Quellen, herausgegeben von der historischen Kommission kaiserlichen Akademie der Wissenschaften in Wien, Abteilung 2: Diplomataria et Acta, Band 67, Wien 1912 [cytowane jako Wolkan III].

Der Briefwechsel des Eneas Silvius Piccolomini, herausgegeben von Rudolf Wolkan, Abteilung 2: Briefe als Bisch of von Siena, Band 1: Briefe von seiner Erhebung zum Bischof von Siena bis zum Ausgang der Regensburger Reistages (23 LX 1450-1 VI 1454), w: Fontes rerum Austriacarum - Österreichische Geschichts-Quellen, herausgegeben von der historischen Kommission kaiserlichen Akademie der Wissenschaften in Wien, Abteilung 3: Diplomataria et Acta, Band 68, Wien 1918 [cytowane jako Wolkan IV].

Codex epistolaris saeculi decimi quinti, ed. J. Szujski, t. 1, cz. 2, w: Monumenta medii aevi historica, t. 2, Kraków 1876.

Codex epistolaris saeculi decimi quinti, ed. A. Lewicki, t. 3, Monumenta medii aevi historica, t. 14, Kraków 1894. 


\section{Opracowania}

Berger-Mayerowa J., O Bibliotece Szembeków, „Sprawozdania Wrocławskiego Towarzystwa Naukowego", 11 (1956) seria A, s. 56-57.

Dzieduszycki M., Zbigniew Oleśnicki, t. 1-2, Kraków 1853-1854.

Mańkowska H., Sekcja rękopisów, w: Biblioteka Katolickiego Uniwersytetu Lubelskiego 1918-1970, „Archiwa, Biblioteki i Muzea Kościelne”, 23, (1971) s. $140-146$ (s. 124-130).

Michalski W., Oddziat gromadzenia i uzupelniania zbiorów w latach 1944-1970, w: Biblioteka Katolickiego Uniwersytetu Lubelskiego 1918-1970, „Archiwa, Biblioteki i Muzea Kościelne", 23 (1971) s. 69-86 (s. 53-70).

Przeździecki A., Wiadomość bibliograficzna o rekopismach zawierajacych $w$ sobie rzeczy polskie przejrzanych po niektórych bibliotekach i archiwach zagranicznych w latach 1846-1849, Warszawa 1850.

Sawicki J., Synody diecezji poznańskiej i ich statuty, w: Concilia Poloniae, t. 7, Poznań 1952.

Szembek Józef, w: Encyklopedia kościelna, wyd. M. Nowodworski, t. 27, Warszawa 1904, s. 512-514.

Slownik Pracowników Ksiqżki Polskiej, red. 1. Treichel, Warszawa - Łódź 1972.

Voigt G., Enea Silvio de'Piccolomini als Papst Pius der Zweite und sein Zeitalter, Band 1-2, Buch 1-3, Berlin 1856-1862.

Wolkan R., Die Briefe des Eneas Silvius vor seiner Erhebung auf den päpstlichen Stuhl, w: Archiv für österreichische Geschichte, herausgegeben von der zur Pflege vaterländischer Geschichte aufgestelten Kommission der kaiserlichen Akademie der Wissenschafien, Band 93, Wien 1905, s. 351-369.

Zarębski I., Stosunki Eneasza Sylwiusza z Polska i Polakami, Kraków 1939.

Zbiory rekkopisów w bibliotekach i muzeach $w$ Polsce, oprac. D. Kumolowa, Warszawa 1988. 


\section{DER HANDSCHRIFTLICHE CODEX AUS DEM 15. JAHRHUNDERT MIT BRIEFEN UND REDEN VON ENEA SILVIO DE PICCOLOMINI AUS DEN SAMMLUNGEN DER UNIVERSITÄTSBIBLIO'THEK DER KUL}

\section{Zusammenfassung}

Der Artikel behandelt den handschriftlichen Codex aus dem 15. Jahrhundert mit Briefen und Reden von Enea Silvio de Piccolomini (Papst Pius II.), der in den Manuskriptsammlungen der Universitätsbibliothek der Katholischen Universität Lublin unter der Signaturnummer 2625 aufbewahrt wird. Es handelt sich um einen Papiercodex in quarto mit 32 Bögen und 588 Seiten, in gotischer und humanistischer Kursiv von mehreren Händen geschrieben. Er stammt aus der Bibliothek des Grafen Jerzy Szembek aus Poreba und war Prof. Józef Szujski bekannt, der ihn bei der Herausgabe des "Codex epistolaris saeculi decimi quinti“" (Band I, Kraków 1876) benutzte, sowie Ignacy Zarebski, der ihn in seiner Arbeit „Die Beziehungen von Enea Silvio de Piccolomini zu Polen und den Polen“ (Kraków 1939) mehrfach zitierte. Die Handschrift betrifft die diplomatische Tätigkeit von Enea Silvio de Piccolomini in den Jahren 1443-1455, hauptsächlich aus der Zeit, als er Bischof von Triest und Siena war. Es handelt sich um von ihm verfaßte und an ihn adressierte Privatbriefe und Amtsschreiben sowie um Reden, die er auf den Reichstagen in Regensburg und Frankfurt (1454) sowie in Neustadt hielt. Neben diesen Reden Piccolominis enthält der Codex auch einige Reden des Bischofs von Pavia Johannes de Castilonio aus dem Jahre 1454 sowie eine Rede des Varadiner Bischofs János Vitéz von 1455 und eine Rede von Bischof Wilhelm von Toulon aus dem Jahre 1454. Ein Teil der in Manuskript der Bibliothek der Katholischen Universität Lublin enthaltenen Briefe Piccolominis ist allgemein bekannt; sie wurden bereits im 15. und 16. Jahrhundert veröffentlicht (unter anderem in einer Nürnberger und Baseler Ausgabe) und dann auch von Georg Voigt und Rudolf Wolkan. Aber ein Teil von ihnen ist bisher völlig unbekannt und unveröffentlicht geblieben. Außerdem enthalten sogar die bekannten Briefe manchmal andere Wortvarianten sowie eine andere Datierung. Der Codex betrifft auch polnische Angelegenheiten, unter anderem enthält er einen Brief von Zbigniew Olesnicki an Enea Silvio de Piccolomini vom 10. September 1453 sowie einen Brief von Enea an Zbigniew vom 26. Mai 1451 oder von Enea an Johannes Carvaial vom Ende des Jahres 1445 über den bei Warna gefallenen polnischen Königs Wladyslaw. Diese Handschrift stellt zweifellos eine wertvolle historische Quelle dar und kann allen, die sich für das Wirken und Schaffen von Enea Silvio de Piccolomini sowie für die Geschichte Europas im 15. Jahrhundert und die polnische Mediävistik überhaupt interessieren, einige wesentliche Details bieten. 